\title{
5. MAGNETIC SULFIDE DIAGENESIS, THERMAL OVERPRINTING, AND PALEOMAGNETISM OF ACCRETIONARY WEDGE AND CONVERGENT MARGIN SEDIMENTS FROM THE CHILE TRIPLE JUNCTION REGION ${ }^{1}$
}

\author{
Robert J. Musgrave, ${ }^{2}$ Hélène Collombat, ${ }^{3}$ and Alexei N. Didenko ${ }^{4}$
}

\begin{abstract}
Shipboard paleomagnetic study of sediments from Leg 141 was hampered by overprinting that resisted alternating field (AF) demagnetization. Post-cruise paleomagnetic and rock magnetic analysis included thermal demagnetization of remanence in air, Curie point determination in helium, isothermal remanence (IRM) acquisition, IRM saturation coercivity, and hysteresis. These studies revealed the presence in almost all samples of a magnetic phase that decomposes on heating in air at $300^{\circ} \mathrm{C}$, decomposes more slowly during heating in a helium atmosphere after vacuum purging, reaches IRM saturation in applied pulsed fields between 0.2 and $0.6 \mathrm{~T}$, and has high coercivity in $300-\mathrm{Hz}$ demagnetization fields. These properties identify this phase as a magnetic iron sulfide, either greigite or pyrrhotite. Hysteresis and thermal demagnetization studies imply that the generation of this phase is associated with the dissolution of fine-grained magnetite. Greigite has been identified as an intermediate step in the microbiological production of pyrite, and these results, together with scanning electron microscope observation of spheroids of amorphous material associated with pyrite in fractures and "dark seams," suggest that greigite and/or pyrrhotite has been generated in these samples by the oxidation of organic matter involving reduction of magnetite. The shape and grain size of the spheroids is consistent with their production by dissimilatory (rather than magnetotactic) bacteria.

Thermal and AF demagnetization, hysteresis, and IRM coercivity in samples from the vertically bedded sequence in Hole 863B indicate a marked reduction in the proportion of fine-grained magnetite below 500 mbsf. Reduction of magnetite has evidently proceeded farther below $500 \mathrm{mbsf}$. This increased reduction of magnetite may have resulted from the flow of hydrocarbon- and $\mathrm{H}_{2} \mathrm{~S}$-rich fluids through this vertically bedded fluid conduit, which matches other diagenetic and geochemical evidence for past flow through this interval.

Thermal demagnetization of remanence of a sample from Site 859 at $228.3 \mathrm{mbsf}$ appears to indicate a partial thermal overprint. Blocking temperature-time analysis indicates that this component was acquired over a range of temperatures from about $90^{\circ} \mathrm{C}$ over $1000 \mathrm{yr}$, to about $120^{\circ} \mathrm{C}$ over $10 \mathrm{yr}$. These temperatures agree broadly with estimates of current fluid flow at temperatures of $>60^{\circ} \mathrm{C}$ from temperature probe measurements at $245 \mathrm{mbsf}$, and imply a past history of similar short-lived, high-temperature fluid flow at various intervals within the sequence at Site 859.

In contrast, no evidence of thermal overprinting was seen in samples from sediments overlying the basement at Site 862 . Hydrothermal activity, if present locally, was apparently limited to the zone of obvious sediment pigmentation, or was at temperatures sufficiently low that any partial thermal remanence acquired has since relaxed. The characteristic magnetization throughout the sediment sequence at Site 862 appears to be normally polarized. Either sedimentation at this site was markedly noncontinuous, or the paleontological age assignments ranging from the late Pliocene through the Pleistocene for this sequence are incorrect. Structural orientation based on the characteristic magnetization indicates that structures at this site developed in response to gravity sliding, and are consistent with an origin for the Taitao Ridge away from a spreading axis.
\end{abstract}

\section{INTRODUCTION}

Ocean Drilling Program (ODP) Leg 141 examined the effects on an accretionary wedge of the approach and subduction of a spreading ridge (Behrmann, Lewis, Musgrave, et al., 1992). An expected consequence was the introduction of hot fluids from the hydrothermal circulation system of the spreading ridge into the wedge, where they were expected to be superimposed on a dewatering-driven fluid flow. To our surprise, relatively modest evidence was seen for such hydrothermal fluid activity.

Site 859 was drilled near the toe of the accretionary wedge about $18 \mathrm{~km}$ north of the triple junction, at a point where the axis of spreading had entered the trench but had not yet been subducted (see location map for this volume). This was the only site on the leg to provide direct evidence of the flow of heated fluids. Downhole temperature measurements by the water sampling temperature probe (WSTP) were interpreted to indicate a narrow "spike" of elevated

\footnotetext{
1 Lewis, S.D., Behrmann, J.H., Musgrave, R.J., and Cande, S.C. (Eds.), 1995. Proc. $O D P$, Sci. Results, 141: College Station, TX (Ocean Drilling Program).

${ }_{2}^{2}$ Geology Department, La Trobe University, Bundoora, VIC 3083, Australia.

${ }^{3}$ Mission ORSTOM, Apartado postal 17-11-06596, Quito, Ecuador.

${ }^{4}$ Institute of the Physics of the Earth. Academy of Science, St. Bolshaya Gruzinskaya 10. Moscow, 123810, Russia.
}

temperatures of at least $43^{\circ} \mathrm{C}$ (possibly greater than $61^{\circ} \mathrm{C}$ ) at about $245 \mathrm{~m}$ below seafloor (mbsf) in Hole $859 \mathrm{~B}$, and set within a broader temperature minimum from about 220 to about $260 \mathrm{mbsf}$, which included temperatures apparently as low as $4.6^{\circ} \mathrm{C}$ (Shipboard Scientific Party, 1992b). The hot spike was thought to arise from the localized flow of heated fluids, presumably in a very restricted conduit (a fault?). The setting of the hot spike within the broader temperature minimum suggests that the flow pattern responsible for it was established recently, and that it cut across a pre-existing, broader flow system involving cold water brought from the near surface. Logging measurements conducted in this hole after drilling generally supported the existence of both the broad low-temperature zone and the narrow hot spike, although both temperature extremes were suppressed by mixing with borehole fluid.

No evidence was seen at other sites on this leg for currently active flow of water of elevated temperatures. This was particularly surprising in the case of Site 863 , which lies directly over the subducted spreading ridge, where hydrothermal flow had been expected most. There was geochemical and diagenetic evidence for a "diagenetic front" possibly related to past fluid flow from about 400 to 500 mbsf in Unit II (Shipboard Scientific Party, 1992d). Evidence that this may have involved heated fluids comes from the presence of silicified foraminifers and fine veins of calcite, quartz, and other authigenic minerals localized in deformation bands below about 325 
mbsf and the high concentrations of gasoline-range hydrocarbons over the same depth interval. Neither Site 860 nor Site 861 presented any clear evidence for hydrothermal fluid flow. At Site 862, which sits atop the volcanic Taitao Ridge in an environment quite distinct from that of the accretionary wedge (Bangs et al., 1992), a 20- to 40-mthick sediment sequence was sampled which included a $70-\mathrm{cm}$-thick discolored zone near its basal contact with volcanics; this zone was interpreted to represent past hydrothermal alteration from late-stage exhalative fluids from the Taitao Ridge volcanism (Shipboard Scientific Party, 1992c).

We collected paleomagnetic samples on Leg 141 for the purpose of detecting past episodes of hydrothermal fluid flow and for estimating the temperatures and duration of such flow. The intention was to conduct stepwise thermal demagnetization of remanence to isolate overprint components of magnetization that could be attributed to partial thermal remanent magnetization (pTRM). Partial thermal remanence results from the fact that the relaxation times of magnetic domains are dependent in an approximately logarithmic fashion on temperature. A rock or sediment will generally contain domains spanning a range of temperature versus relaxation-time curves, which correspond to variations in chemistry, mineralogy, grain size, and other factors, including the presence of inclusions and the state of strain of the grain. When a material is heated, some domains that were formerly stable over geologically significant time periods will now have relaxation times sufficiently short that the domains will readjust their magnetization toward the ambient field direction. Part or all of the preexisting magnetization will be replaced by an unstable magnetization component in the ambient field direction. If the temperature then decreases, the relaxation times of all domains will increase, and some of the formerly unstable domains will now have relaxation times of geologically significant length. This process "blocks in" a magnetization component with the direction of the ambient magnetic field of the time. If this field direction relative to the rock or sediment is different from the original field direction (owing to apparent polar wander related to plate motion, secular variation, magnetic polarity reversal, or a structural change in the orientation of the rock or sediment), the magnetic "overprint" that results will be detectable during stepwise thermal demagnetization of remanence as a separate magnetization component vectorially removed over a certain range of laboratory "unblocking" temperatures. The upper limit of demagnetization temperatures required to "unblock" this component, together with the time that this temperature is maintained in the field-free space of the demagnetizer prior to sudden cooling, give a point in temperature-relaxation time space that fixes which curve represents this set of domains. This can be done uniquely, at least for single-domain (SD) and pseudosingle-domain (PSD) grains, providing we know which set of curves to apply (principally controlled by the mineralogy and chemistry of the magnetic carriers). We can then predict the in-situ temperatures that could have produced this overprint, for a given period for which the elevated temperature was maintained.

\section{SUMMARY OF SHIPBOARD AF-DEMAGNETIZATION RESULTS AND INTERPRETATIONS}

Thermal demagnetization of these samples was also favored, because shipboard alternating field (AF) demagnetization of continuous cores and discrete samples had failed to completely remove overprinting (for detailed descriptions see site chapters in Behrmann, Lewis, Musgrave, et al., 1992, and Shipboard Scientific Party, 1992a, for shipboard techniques). The form and degree of this overprinting varied from site to site, and with depth within sites.

\section{Site 859}

At Site 859, an overprint with a negative inclination affected most samples, and this was only partly removed by the $15-\mathrm{mT}$ demagneti- zation applied to continuous core sections. Nevertheless, we were able to define an apparently reliable (if discontinuous) magnetostratigraphy from about 220 to about 400 mbsf. In the "folded domain," defined structurally above $80 \mathrm{mbsf}$, this overprint was removed by $25-\mathrm{mT}$ demagnetization. Below the folded domain, the overprint had a much higher resistance to AF demagnetization; demagnetized directions in discrete samples in this interval had not stabilized even at the maximum demagnetization applied, $50 \mathrm{mT}$. The inclination of this overprint is close to that of the dipole field expected at this latitude $\left(-65^{\circ}\right)$, from which we inferred that it probably arose as a viscous remanent magnetization (VRM). There was little evidence at this site of near-vertically inclined overprints of the type described on several other ODP and Deep Sea Drilling Project (DSDP) legs (e.g., Barton and Bloemendal, 1986; Bleil, 1989; Tauxe et al., 1989; Hall and Sager, 1990; Hounslow et al., 1990; Kroenke, Berger, Janecek, et al., 1991), which have been ascribed to remagnetization (IRM, or shock induced) resulting from intense magnetization of the drill pipe or core barrel (a "coring-induced remanence," see Musgrave et al., 1993).

\section{Sites 860 and 861}

Overprinting at Sites 860 and 861 presented a more severe problem, which together with poor core recovery prevented recognition of a magnetostratigraphy in the continuous-core measurements. Natural remanent magnetization (NRM) inclinations were almost uniformly negative, and generally between $-60^{\circ}$ and $-90^{\circ}$; the near-vertical inclinations were too steep to represent a VRM, and suggested the presence of a coring-induced remanence. AF demagnetization of some discrete samples from these two sites showed the presence of a proportionally large negative-inclination overprint, which dominated the remanence at demagnetization fields of less than $20 \mathrm{mT}$. This overprint obscured a reversed characteristic remanence (ChRM). Inclinations of the ChRM remained anomalously low at the maximum demagnetization fields used (about $50 \mathrm{mT}$ ); although this could represent an extreme case of sedimentary inclination shallowing (Arason and Levi, 1990; Deamer and Kodama, 1990; Tarduno, 1990), it is more likely that the overprint has been incompletely removed here, again implying a high AF coercivity. Other samples at Sites 860 and 861 demagnetized to a stable end point above $15-30 \mathrm{mT}$, implying a lack of a similar overprint with high $\mathrm{AF}$ coercivity in these samples.

A single sample from the deepest core at Site 861, which sampled a shear zone within the broken formation, showed evidence of what appeared to be a positive-inclination (reversed polarity) overprint, which persisted to at least $13 \mathrm{mT}$. A reversed polarity overprint cannot represent an in-situ VRM.

\section{Site 862}

NRM inclinations from the three cores in Hole $862 \mathrm{~A}$ were uniformly negative, and continuous-core NRM inclinations in Cores 141-862A$1 \mathrm{H}$ and $-3 \mathrm{H}$ were mostly steeper than the expected VRM inclination of $-65^{\circ}$. Core $141-862 \mathrm{~A}-2 \mathrm{H}$ was less strongly overprinted, as shown by the ratio of 15-mT-demagnetized intensity over NRM (see figure 21 in Shipboard Scientific Party, 1992c), and the sharp demarcations of overprint intensity at core boundaries imply that this overprint arose as a coring-related remanence. The remanence direction in discrete samples from Cores $141-862 \mathrm{~A}-1 \mathrm{H}$ and $-2 \mathrm{H}$ became stable at demagnetization levels above $15 \mathrm{mT}$, suggesting that the characteristic remanence had been isolated; this was normally polarized in all samples, although the inclination in some samples was anomalously low after taking the bedding into account. These sediments are covered by less than $20 \mathrm{~m}$ of overburden, so post-depositional inclination shallowing as a result of compaction would not be expected. However, shallowing may have occurred during deposition, and may be related to grain imbrication caused by strong contour current activity, as probable contourites were identified through this sequence. $\mathrm{AF}$ demagnetization of two discrete samples from Sections 141-862A-3H-2 and -3 revealed more complex 
demagnetization paths. Hydrothermal alteration of the sediments extending for about $1 \mathrm{~m}$ above the contact with igneous basement at this site was indicated by a brownish to yellowish coloration and by the presence of sulfide minerals. The complex AF demagnetization paths were thought to represent multiple magnetic overprints in the sediments, extending to at least $4.25 \mathrm{~m}$ above basement, about $3.5 \mathrm{~m}$ above the top of obvious color alteration in the sediments; this in turn was interpreted as representing continued hydrothermal activity resulting in the acquisition of partial thermal remanences. The remanence inclination of Sample 141-862A-3H-3, 91-92 cm, decreased systematically to the highest demagnetization applied $(40 \mathrm{mT})$, implying that the ChRM, which was not isolated, was either near horizontal (after correction for bedding) or possibly reversely polarized.

\section{Site 863}

AF demagnetization of both continuous-core and discrete samples from Site 863 again emphasized the significance of a negativeinclination overprint, which was commonly near vertical, implying the presence of a coring-induced overprint, probably in addition to a VRM. Overprinting was at its most severe in sediments from Subunit IA and the upper part of Subunit IB, as demonstrated by the highly convex demagnetized intensity plots of the discrete samples from this interval. The demagnetization path of these samples was complex, implying either in-situ overprinting or a susceptibility to the acquisition of coring-induced and/or laboratory acquired components, which we hypothesized may be carried by magnetic sulfides associated with the zones of concentrated organic matter and amorphous sulfides found in this interval. Magnetic overprinting related to the presence of iron sulfides, either greigite or pyrrhotite, has been inferred in other ODP studies (Sager, 1988; Musgrave et al., 1993; Westbrook, Carson, Musgrave, et al., 1994).

Overprinting by coring-induced and/or viscous remanence remained severe in Subunit IIA and the upper part of Subunit IIB (from 104 to about $300 \mathrm{mbsf}$ ), although complex additional overprints were absent, consistent with the observation of a substantial reduction in the quantity of sulfides present relative to Unit I. These samples again displayed highly convex demagnetization intensity plots, and most demagnetized along a single, long, great-circle path. Some reached a stable end point at about $30-40 \mathrm{mT}$, but overprinting appeared to persist in others to at least $50 \mathrm{mT}$.

Overprinting was reduced in intensity between the top of the recovered interval in Hole 863B (325.9 mbsf) and about $500 \mathrm{mbsf}$. Demagnetized inclinations of the continuous core in this interval averaged about $-10^{\circ}$ to $-20^{\circ}$, appropriate (taking the near-vertical dip of the bedding of this interval into account) to represent a depositional or early post-depositional ChRM, indicating near-complete removal of VRM and any coring-induced component by a 15-mT AF. Most discrete samples from this interval had almost linear AF demagnetization intensity plots, with generally small VRM or coring-induced components removed from the VRM by $10-20-\mathrm{mT}$ demagnetization.

Below 500 mbsf overprinting was more severe, as indicated by inclinations in the continuous core record of about $-60^{\circ}$ after $15-\mathrm{mT}$ demagnetization (this inclination cannot represent a depositional ChRM given the near-vertical dip of these beds). A short interval of less intense overprinting was again evident from about 675 to about $725 \mathrm{mbsf}$.

\section{POST-CRUISE ANALYTICAL METHODS}

Discrete samples were taken by pressing standard ODP plastic boxes $(2.1 \times 2.1 \times 1.5 \mathrm{~cm})$ into soft silts and clays. Stiffer sediments were cut with a stainless-steel knife, and semilithified material with parallel saw blades, and these samples were also placed into ODP boxes. More lithified silts and clays were sampled as cylinders cut with the 2.5 -cm-diameter minidrill apparatus. Samples in the silts and clays were taken only from parts of the core that displayed no evidence of "flow-in" or other sampling disruption. Where semilithified material had been biscuited, samples were taken in segments long enough to allow confidence that the segment had not been rotated about a horizontal axis.

A small subset of boxed samples from Site 859 (from Cores 141-859B-1R through -18R) was stepwise thermally demagnetized on board, using a shielded Schonstedt furnace/cooling chamber unit. The remanence of the samples after each step was measured with a Molspin Minispin spinner magnetometer. The samples were initially heated through demagnetization steps of $40^{\circ}, 60^{\circ}, 80^{\circ}$ and $100^{\circ} \mathrm{C}$ while still in their plastic boxes, allowing them to slowly dry. Following the $100^{\circ} \mathrm{C}$ step (sometimes delayed to the $120^{\circ} \mathrm{C}$ step), the samples were removed (where possible) whole from their boxes. Samples that could be successfully removed were further demagnetized at $20^{\circ} \mathrm{C}$ steps to $600^{\circ} \mathrm{C}$ or destruction of the sample. After cooling following each heating, the samples were returned (maintaining their orientation) to their boxes for measurement. The boxes were themselves AF demagnetized to minimize their contribution to the measured remanence.

Post-cruise thermal demagnetization of remanence studies were conducted at the paleomagnetic laboratory of the Department of Geology, Texas A\&M University. The same procedure was followed for additional boxed samples, which represented all sites drilled on Leg 141. Cylindrical samples of the lithified materials were thermally demagnetized through the same steps. All analysis at the Texas A\&M facility was conducted inside a magnetically shielded room.

A subset of samples was also prepared for IRM analysis at the Texas A\&M paleomagnetic laboratory. Samples were initially AF demagnetized at $5-\mathrm{mT}$ steps to $50 \mathrm{mT}$. Isothermal remanences were then applied using a pulsed-field device, up to a maximum of about $1.2 \mathrm{~T}$.

Other samples were taken to the Institute for Rock Magnetism in Minneapolis. Samples were AF demagnetized with a Schonstedt GSD-1 demagnetizer in $10-\mathrm{mT}$ steps to $60 \mathrm{mT}$. Samples were then given an isothermal remanence in 10-mT AF steps up to $0.5 \mathrm{~T}$ (sufficient for saturation in all samples measured). A back-field was then applied and increased until the saturation remanence was completely removed; the field required to do this defined the coercivity of remanence, $\mathrm{H}_{\mathrm{cr}}$. Hysteresis for some complete samples was then determined with a Princeton Applied Research vibrating sample magnetometer (VSM). Hysteresis for other samples was measured on small subsamples (about 2-5 mg) using a Micro-Mag alternating gradient force magnetometer: this instrument was preferred because of its faster cycling time. Hysteresis curves were corrected for the paramagnetic component. Saturation magnetizations were calculated on a weight basis; this was approximately converted to a volume basis by assuming a density of $2 \mathrm{Mg} / \mathrm{m}^{3}$, a suitable average based on shipboard physical properties measurements. Temperature dependence of saturation magnetization (usually referred to as Curie point measurement) was measured for both heating and cooling runs in a furnace fitted to the VSM, in applied fields ranging from 300 to $500 \mathrm{mT}$, which is sufficient for magnetite saturation. Small subsamples, typically $0.1-$ $0.15 \mathrm{~g}$ in mass, were used in this instrument, and the samples were purged with $\mathrm{He}$ and heated in a He-filled chamber to remove most of their contained air and so reduce alteration due to oxidation during heating. The heating run was continued to a maximum temperature of $650^{\circ} \mathrm{C}$.

\section{RESULTS}

\section{Thermal Demagnetization of Remanence}

Most samples, from all sites, are characterized by an inflection that marks an abrupt increase in the rate of demagnetization in their demagnetized intensity curves at about $300^{\circ} \mathrm{C}$ (Fig. 1). This inflection is also seen in some samples as a break between two distinct trends of the demagnetization vector on a Schmidt plot (Fig. 2). There appear to be three components present: the first (component " $\mathrm{A}$ ") restricted to temperatures of less than $300^{\circ} \mathrm{C}$; a second (component " $\mathrm{B}$ ") with a demagnetization spectrum extending over all or most of the demag- 


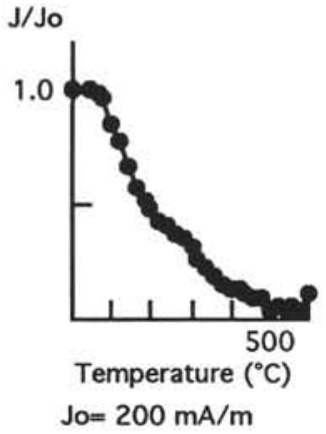

$141-859 \mathrm{~A}-14 \mathrm{X}-2,21-23 \mathrm{~cm}$

$\mathrm{J} / \mathrm{Jo}$

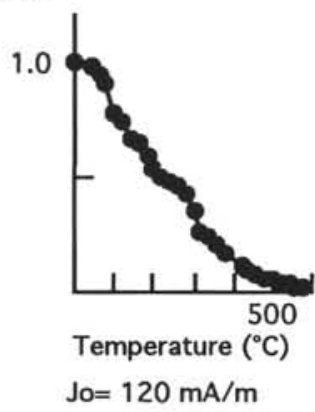

$141-862 \mathrm{~A}-3 \mathrm{H}-2,64-66 \mathrm{~cm}$

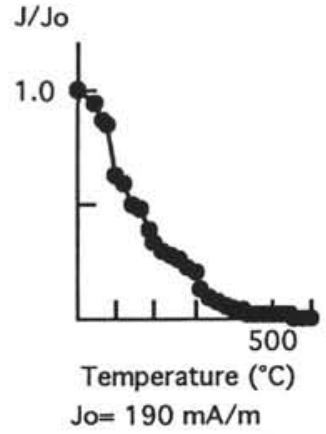

$141-860 \mathrm{~B}-64 \mathrm{X}-4,58-60 \mathrm{~cm}$

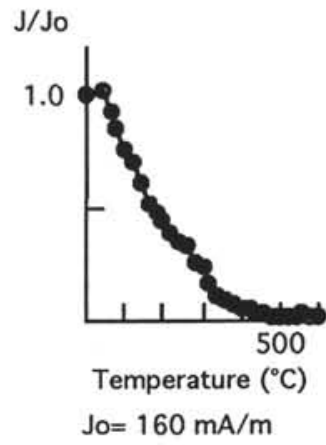

$141-863 B-21 R-2,37-39 \mathrm{~cm}$

Figure 1. Demagnetized intensity curves showing remanence intensity (J) normalized by NRM intensity (Jo) vs. temperature for typical thermal demagnetization of remanence runs of Leg 141 sediments. Note the inflection at about $300^{\circ} \mathrm{C}$.

netization range from the NRM to $600^{\circ} \mathrm{C}$; and a third (component "C") which also demagnetizes over a wide temperature range, but with a stability spectrum biased towards higher temperatures. The demagnetization trend below $300^{\circ} \mathrm{C}$ results primarily from the overlap of the stability spectra of components $\mathrm{A}$ and $\mathrm{B}$; the trend above $300^{\circ} \mathrm{C}$ results from the overlap of components $\mathrm{B}$ and $\mathrm{C}$. Component A (which is small or absent in many samples) appears to have a steep negative inclination, and by analogy to the shipboard results we interpret it to be the drilling-induced component. Component $\mathrm{B}$ is not isolated, but probably has a more moderate negative inclination, and is most likely the VRM. Component $\mathrm{C}$ varies from sample to sample, and is presumably the characteristic remanence (a depositional or early post-depositional remanence). In general, the proportion of NRM represented by the drilling-induced component and the total change in direction from the NRM to the higher stages of demagnetization are lower than was observed for shipboard AF demagnetization; this is consistent with the observation of Collombat et al. (this volume) that post-cruise AF-demagnetization of samples indicated the overprint magnetization is dominated by the VRM. This may have resulted from relaxation of the overprint component during post-cruise storage in low-field space, which was the practice in both this study and that of Collombat et al.

\section{Site 859}

The demagnetized intensity curve of Sample 141-859B-13R-3, 91-93 cm, lacks a significant downward inflection at $300^{\circ} \mathrm{C}$, but instead shows a break in slope in the opposite sense at $180^{\circ}-200^{\circ} \mathrm{C}$ (Fig. 3). There is a corresponding change in the direction of the demagnetization vector at $200^{\circ} \mathrm{C}$; again there appear to be two trends (although the trend over higher demagnetization stages is obscured by noise), made up by three components (which we label "D" to "F," from least to most stable). Components $\mathrm{E}$ and $\mathrm{F}$ are not completely isolated, but component $\mathrm{E}$ apparently has a negative inclination (VRM?), whereas component $\mathrm{F}$, the characteristic remanence, has a positive inclination. After removal of soft, post-sampling components at $40^{\circ} \mathrm{C}$, the $40^{\circ} \mathrm{C}$ to $100^{\circ} \mathrm{C}$ steps are tightly grouped with an inclination of $-60^{\circ}$, which may represent isolation of component D. Hence component D is normally magnetized, with an inclination roughly that of the dipole field for this latitude.

The demagnetized intensity curves of Samples 141-859B-1R-2, $38-40 \mathrm{~cm}$, and 141-859B-14R-3, 77-79 cm, also have an inflection at about $200^{\circ} \mathrm{C}$, but this does not correspond to a significant change in the path of the demagnetization vector in either sample (Fig. 4). An additional drop in intensity in these samples occurs at about $300^{\circ} \mathrm{C}$, and a change in the trend of their demagnetization vectors (partly obscured by noise) occurs between $300^{\circ}$ and $360^{\circ} \mathrm{C}$. The demagnetized intensity of Sample 141-859B-2R-2, 28-30 cm, lacks any clear inflection, and the demagnetization path of this sample appears to follow a single trend, allowing for some noise at higher demagnetization temperatures. The demagnetization path of Sample 141-859B-33R-2, 64-66 $\mathrm{cm}$, also lacks a clear inflection at about $300^{\circ} \mathrm{C}$, but instead shows a series of four demagnetization trends with sharp changes in trend of declination at $240^{\circ}$ and $340^{\circ} \mathrm{C}$, and inclination at $500^{\circ} \mathrm{C}$ (Fig. 5). Sample 141-859B-18R-5, 92-94 cm, and all samples from Hole 859A show the simple pattern of inflection in intensity and demagnetization vector path at $280^{\circ}-300^{\circ} \mathrm{C}$ (Fig. 6).

\section{Site 862}

Surprisingly, thermal demagnetization of remanence of samples from Core 141-862A-3H (Fig. 7) did not confirm the interpretation of thermal overprinting inferred from the shipboard AF-demagnetization results. Samples 141-862A-3H-2, 64-66 cm, and -3, 139-141 $\mathrm{cm}$, indicated only the $300^{\circ} \mathrm{C}$ inflection common to samples from other sites (the apparent offset in Sample -3H, 139-141 cm, probably 

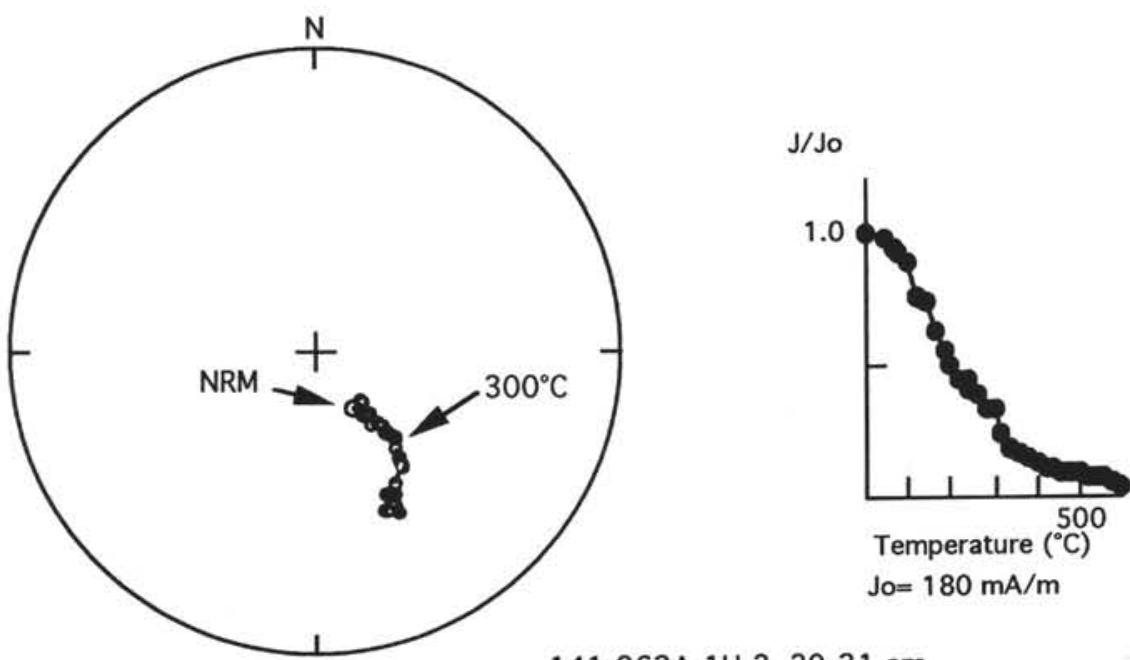

$141-863 \mathrm{~A}-1 \mathrm{H}-2,29-31 \mathrm{~cm}$
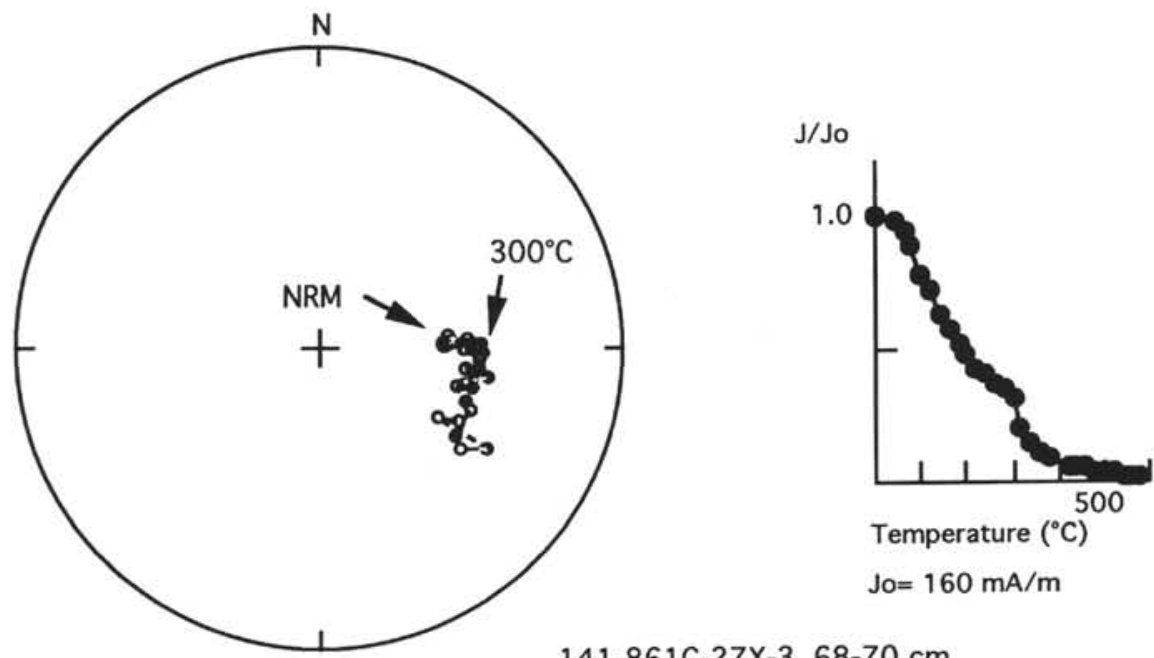

$141-861 \mathrm{C}-27 \mathrm{X}-3,68-70 \mathrm{~cm}$

Figure 2. Schmidt stereographic projections and demagnetized intensity curves for two samples showing a break in demagnetization vector trend associated with the $300^{\circ} \mathrm{C}$ inflection in demagnetized intensity. Open circles on the Schmidt projection represent negative inclinations. The larger circle represents the NRM direction. Demagnetization temperatures are at $20^{\circ} \mathrm{C}$ intervals from $40^{\circ} \mathrm{C}$.

only represents a small misalignment of the sample following its first removal from its plastic box). Thermal demagnetization of remanence of Sample 141-862A-3H-4, 115-117 cm, which was taken from within the "ocher" zone of color change interpreted as hydrothermal alteration, nevertheless showed no obvious thermal overprinting. The only noteworthy difference between this sample and others from this site is the lack of an inflection at $300^{\circ} \mathrm{C}$. All samples from Core 141-862A-3H demagnetized toward a normally polarized characteristic remanence.

\section{Site 863}

Thermal demagnetization of remanence of most samples from throughout Holes $863 \mathrm{~A}$ and $863 \mathrm{~B}$ produces intensity plots with an inflection at $300^{\circ} \mathrm{C}$; however, the behavior above this temperature varies systematically with depth (Fig. 8). All samples from Hole 863A (representing depths down to about $281 \mathrm{mbsf}$ ) demagnetize abruptly with increasing temperature above $300^{\circ} \mathrm{C}$, so that the intensity plot is distinctly "concave" above this temperature. Less than $10 \%$, and generally less than $5 \%$, of the NRM intensity is still present at the $500^{\circ} \mathrm{C}$ step. The shallowest sample from Hole 863B (Sample 141$863 \mathrm{~B}-7 \mathrm{~N}-2,33-35 \mathrm{~cm}$, at about $357 \mathrm{mbsf}$ ) is different; although the $300^{\circ} \mathrm{C}$ inflection is still prominent, demagnetization proceeds more slowly above this temperature, and a substantial proportion $(>10 \%)$ of the NRM intensity persists at the $500^{\circ} \mathrm{C}$ step. All succeeding samples with increasing depth down to Sample 141-863B-20R-1, $41-43 \mathrm{~cm}$, (about $468 \mathrm{mbsf}$ ) behave similarly. Sample 141-863B21R-2, 37-39 cm, (at about $474 \mathrm{mbsf}$ ) follows the pattern of abrupt demagnetization above $300^{\circ} \mathrm{C}$, similar to the samples from Hole $863 \mathrm{~A}$. Sample 141-863B-23R-1, $47-49 \mathrm{~cm}$, reverts to more gradual demagnetization above $300^{\circ} \mathrm{C}$. With the exception of Sample 141863B-46R-1, 99-101 cm, (at about $708 \mathrm{mbsf}$ ) which demagnetizes gradually above $300^{\circ} \mathrm{C}$, all samples below Sample 141-863B-26R-1, $31-33 \mathrm{~cm}$, (i.e., below about $500 \mathrm{mbsf}$ ) demagnetize abruptly above $300^{\circ} \mathrm{C}$, producing a concave intensity curve above this temperature. Some samples from this interval (e.g., Sample 141-863B-26R-1, $31-33 \mathrm{~cm}$ ) show intensity curves which are concave from the NRM step onwards.

\section{IRM Acquisition}

All samples were saturated by applied fields of $0.6 \mathrm{~T}$; most samples were close to saturation at $0.2 \mathrm{~T}$. Magnetite saturates under applied static fields of no more than $0.2 \mathrm{~T}$ (Tarling, 1983). The maxi- 


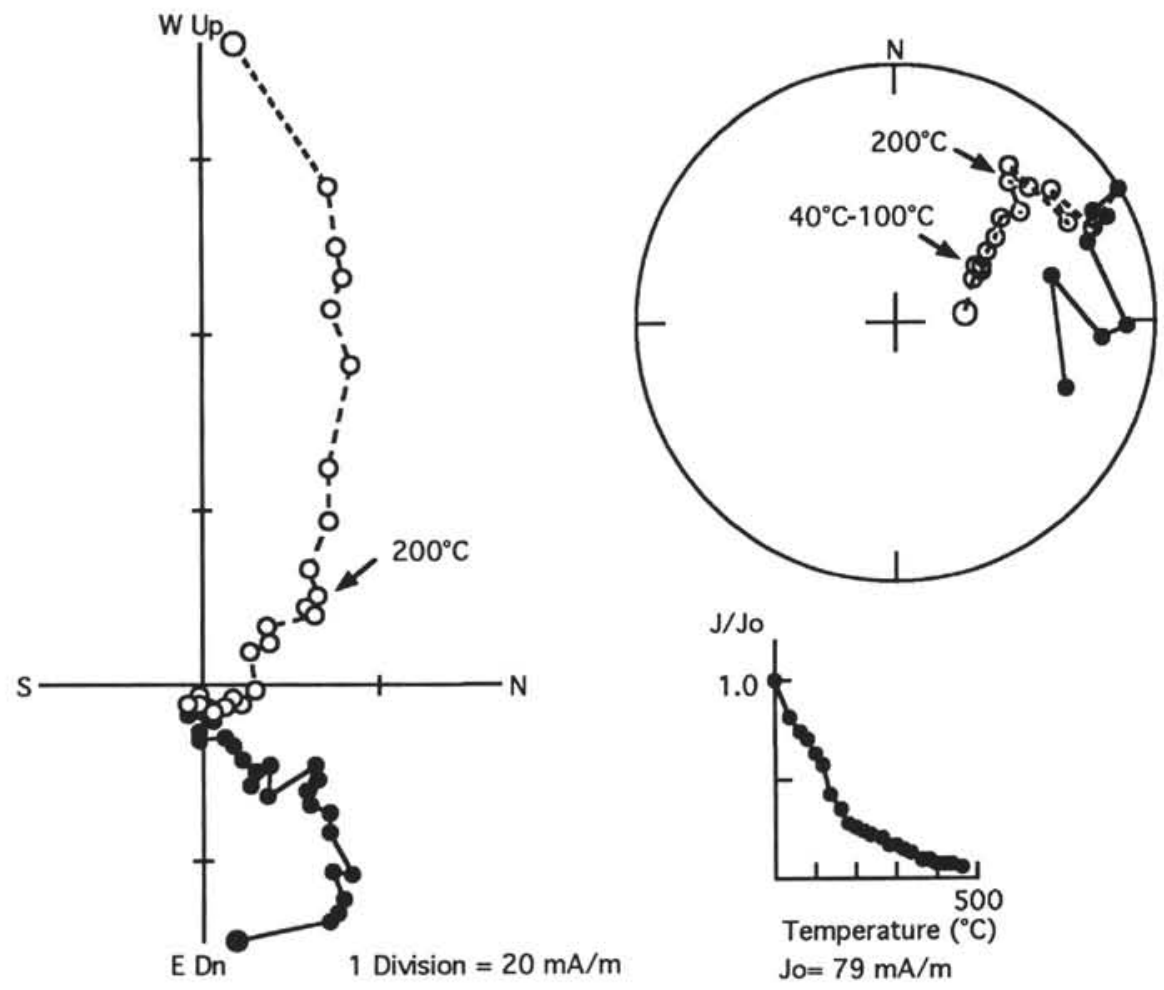

Figure 3. Orthogonal demagnetization vector ("Zijderveld") plot, Schmidt projection, and demagnetized intensity plot of Sample 141-859B-13R-3, 91-93 cm. Solid circles on the Zijderveld plot are projections on the horizontal plane, open circles are projections on the vertical north-south plane. Other symbols and demagnetization temperature intervals as for Figure 2.

mum increase between the IRM at $0.2 \mathrm{~T}$ and the IRM at saturation amounted to about $15 \%$, indicating a significant proportion of a magnetic phase other than magnetite. There was no clear pattern linking saturating field strength with sites, or depth within a particular hole (Fig. 9).

\section{Hysteresis}

Coercivity defined by the hysteresis curve $\left(\mathrm{H}_{c}\right)$ remained roughly constant in the range $9-16 \mathrm{mT}$ through most samples from Sites 859 , 860 , and 861 (Table 1). There are a few exceptions to this range-one lower value (Sample 141-859B-21R-3, 122-124 cm) and two higher values (Samples 141-859B-32R-2, 21-23 cm, and 141-860B-2H-6, 71-73 cm)-but there does not seem to be any pattern to these variations. In contrast, Site 863 shows a systematic variation in coercivity: $\mathrm{H}_{\mathrm{c}}$ lies in the range 6-11 mT for all samples from both Holes $863 \mathrm{~A}$ and 863B down to Sample 141-863B-19R-2, 96-98 cm (about $455 \mathrm{mbsf}$ ), but drops to $3.99 \mathrm{mT}$ in Sample 141-863B-24R-2, 18-20 cm, (about $505 \mathrm{mbsf}$ ) and remains less than $6 \mathrm{mT}$ for the remaining samples to the bottom of Hole 863B. Intriguingly, Sample 141-863B-41R-3, 20-22 $\mathrm{cm}$, which lies near the top of the interval of less intense overprinting seen in the shipboard measurements of continuous core (see above) from about 675 to about $725 \mathrm{mbsf}$, has a slightly higher coercivity $(5.67 \mathrm{mT})$ than the other samples in the lower part of Hole 863B.

Normalizing the back field coercivity of IRM $\left(\mathrm{H}_{\mathrm{cr}}\right)$ against the hysteresis coercivity produced an even more systematic division (Table 1). All samples from Sites 859,860 , and 861 had a $\mathrm{H}_{\mathrm{c}} / \mathrm{H}_{\mathrm{c}}$ ratio of between 2.4 and 4.8. Samples from Holes $863 \mathrm{~A}$ and 863B (Fig. 10) down to and including Sample 141-863B-19R-2, 96-98 cm, have $\mathrm{H}_{\mathrm{cr}} / \mathrm{H}_{\mathrm{c}}$ ratios $\leq 6.24$; excluding the shallowest sample in Hole 863A (Sample 141-863A-3H-4, 63-65 cm), this series of samples (all from above $500 \mathrm{mbsf}$ ) has a $\mathrm{H}_{\mathrm{cr}} / \mathrm{H}_{\mathrm{c}}$ ratio of less than 5.3. All samples from
Hole 863B below and including Sample 141-863B-24R-2, 18-20 cm, have $\mathrm{H}_{\mathrm{cr}} / \mathrm{H}_{\mathrm{c}}$ ratios $\geq 5.77$; excluding Sample 141-863B-41R-3, 20-22 $\mathrm{cm}$, all samples from below $500 \mathrm{mbsf}$ have $\mathrm{H}_{\mathrm{cr}} / \mathrm{H}_{\mathrm{c}}$ ratios $>7.49$.

The ratio $\mathrm{H}_{\mathrm{c}} / \mathrm{H}_{\mathrm{c}}$ provides a measure of the domain state of magnetic minerals. Experimental studies of magnetite grains have shown multidomain (MD) magnetite grains to have a $\mathrm{H}_{\mathrm{cr}} / \mathrm{H}_{\mathrm{c}}$ ratio greater than 4 (Day et al., 1977), and assemblages dominated by superparamagnetic grains to have a ratio greater than 10 (Wasilewski, 1973). The ratio of saturation remanence $\left(\mathrm{J}_{\mathrm{rs}}\right)$ to saturation magnetization $\left(\mathrm{J}_{\mathrm{s}}\right)$ also varies systematically with domain state, and a plot of the two ratios defines fields for SD, PSD and MD grains (Day et al., 1977). Such magnetization versus coercivity plots for samples from Sites 859,860 , and 861 (Fig. 11A) indicate that the majority of samples are dominated by PSD grains (if magnetite is the dominant magnetic carrier), and that there is a trend toward the MD field, with a small proportion of samples apparently being dominated by MD grains. Samples from Site 863 (Fig. 11B) show a trend from near the PSD/MD boundary through the MD field toward the superparamagnetic $\mathrm{H}_{\mathrm{cr}} / \mathrm{H}_{\mathrm{c}}$ range. Samples from Site 863 below 500 mbsf lie exclusively in the MD/superparamagnetic field. Despite this overall trend, the two subsets of data, above and below $500 \mathrm{mbsf}$, show no internal systematic variation with depth.

Plots of saturation remanence normalized by susceptibility against $\mathrm{H}_{\mathrm{cr}}$ can distinguish samples in which $\mathrm{J}_{\mathrm{s}}$ is dominated by superparamagnetic grains from those dominated by PSD and MD grains (Bradshaw and Thompson, 1985). Such a plot (Fig. 12A) confirms that samples from Sites 859,860 , and 861 are dominated by PSD grains, without a significant superparamagnetic component. Samples from above 500 mbsf from Site 863 (Fig. 12B) fall within the PSD field on the $J_{s} / \mathrm{k}$ versus $H_{c r}$ plot, with a trend towards the MD field. Samples below 500 mbsf at Site 863 fall between the PSD and MD fields, and trend down into the superparamagnetic field. 

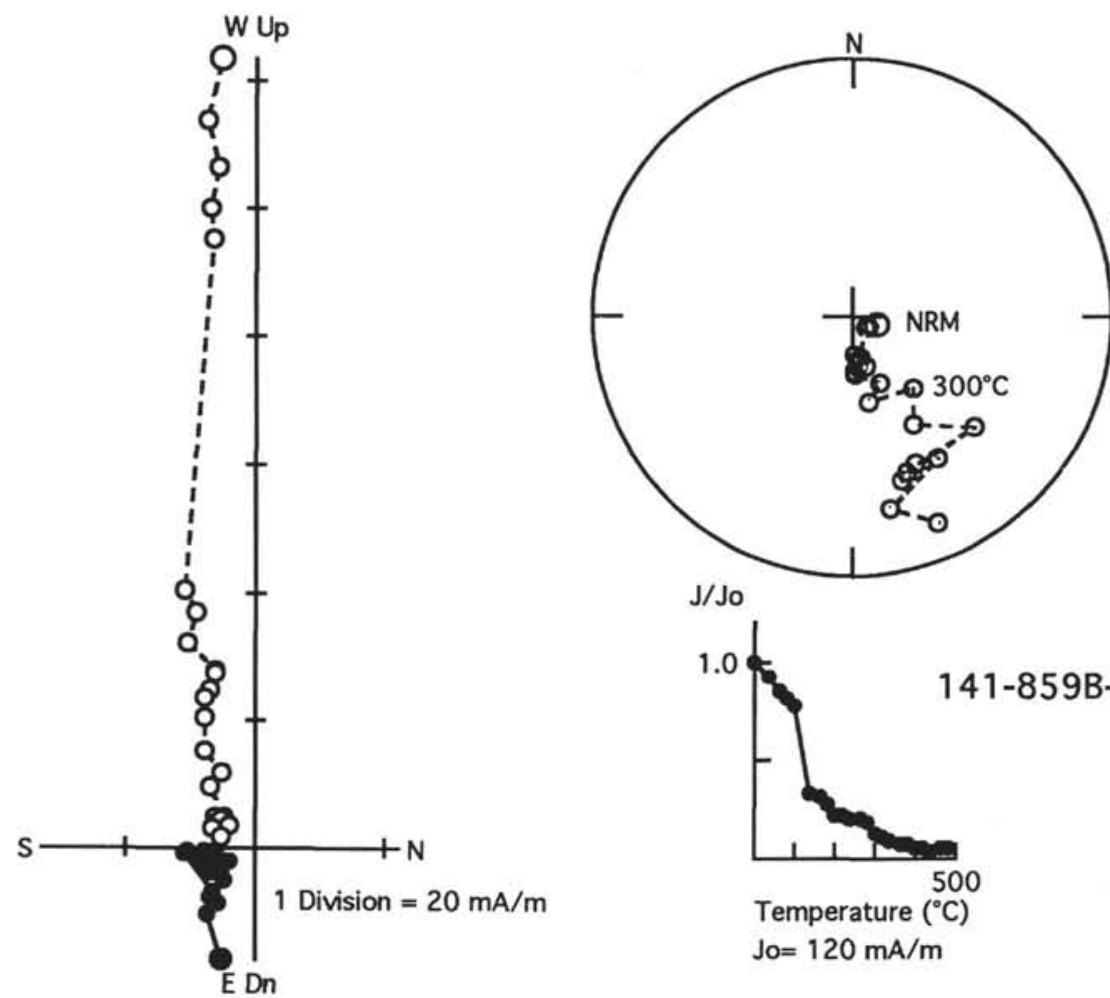

$\mathrm{J} / \mathrm{Jo}$

1.0
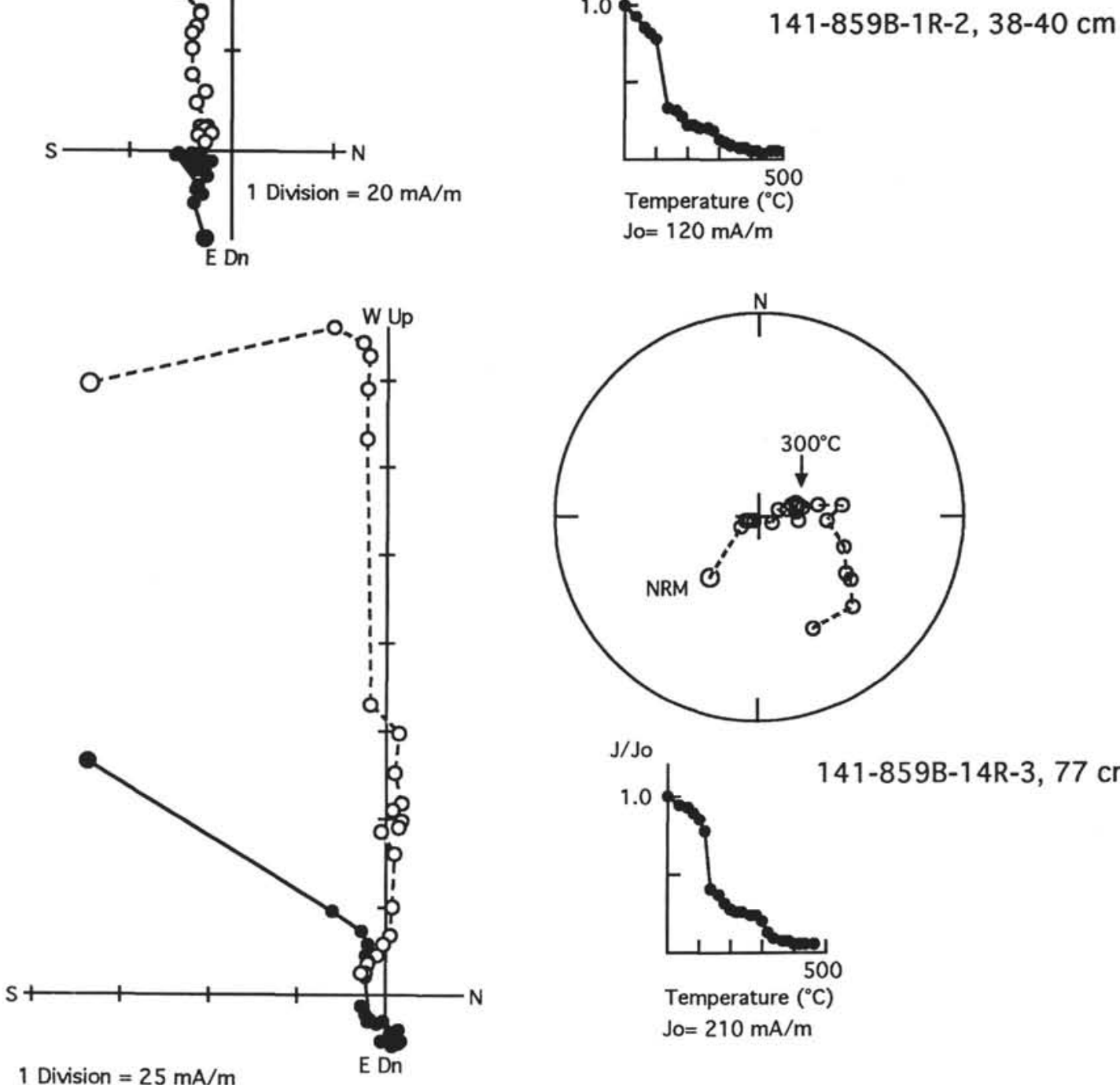

141-859B-14R-3, $77 \mathrm{~cm}$

Temperature $\left({ }^{\circ} \mathrm{C}\right)$

$\mathrm{Jo}=210 \mathrm{~mA} / \mathrm{m}$

Figure 4. Zijderveld plot, Schmidt projection, and demagnetized intensity plots of two samples from Site 859. Symbols and demagnetization intervals as for Figure 3.

\section{Curie Point Determinations}

Thermomagnetic runs in the Curie Point balance showed two contrasting styles. In some samples (Fig. 13) the cooling curve finishes at distinctly higher magnetizations than those at the beginning of the heating curve; such irreversible behavior indicates the genera- tion of new magnetic phases during the heating run. The sample showing the largest difference between the heating and cooling runs (Sample 141-863A-3H-4, 63-65 cm) did not display a clearly marked Curie Point on either the heating or cooling run, and in fact magnetization on the heating run actually began to increase again with increasing temperature after reaching a minimum at about $590^{\circ}-600^{\circ} \mathrm{C}$. 

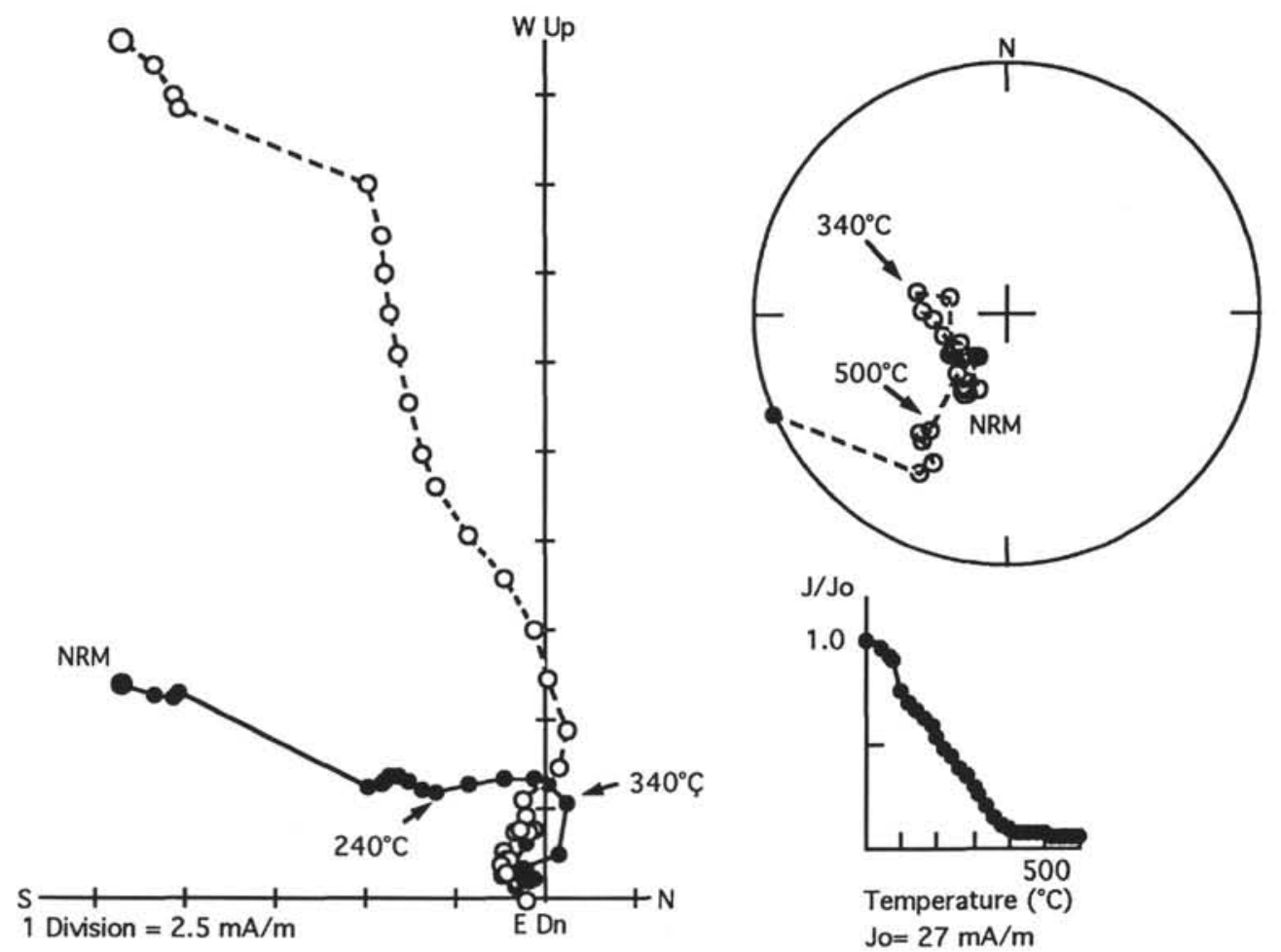

Figure 5. Zijderveld plot, Schmidt projection, and demagnetized intensity plot of Sample 141-859B-33R-2, 64-66 cm. Symbols and demagnetization intervals as for Figure 3.
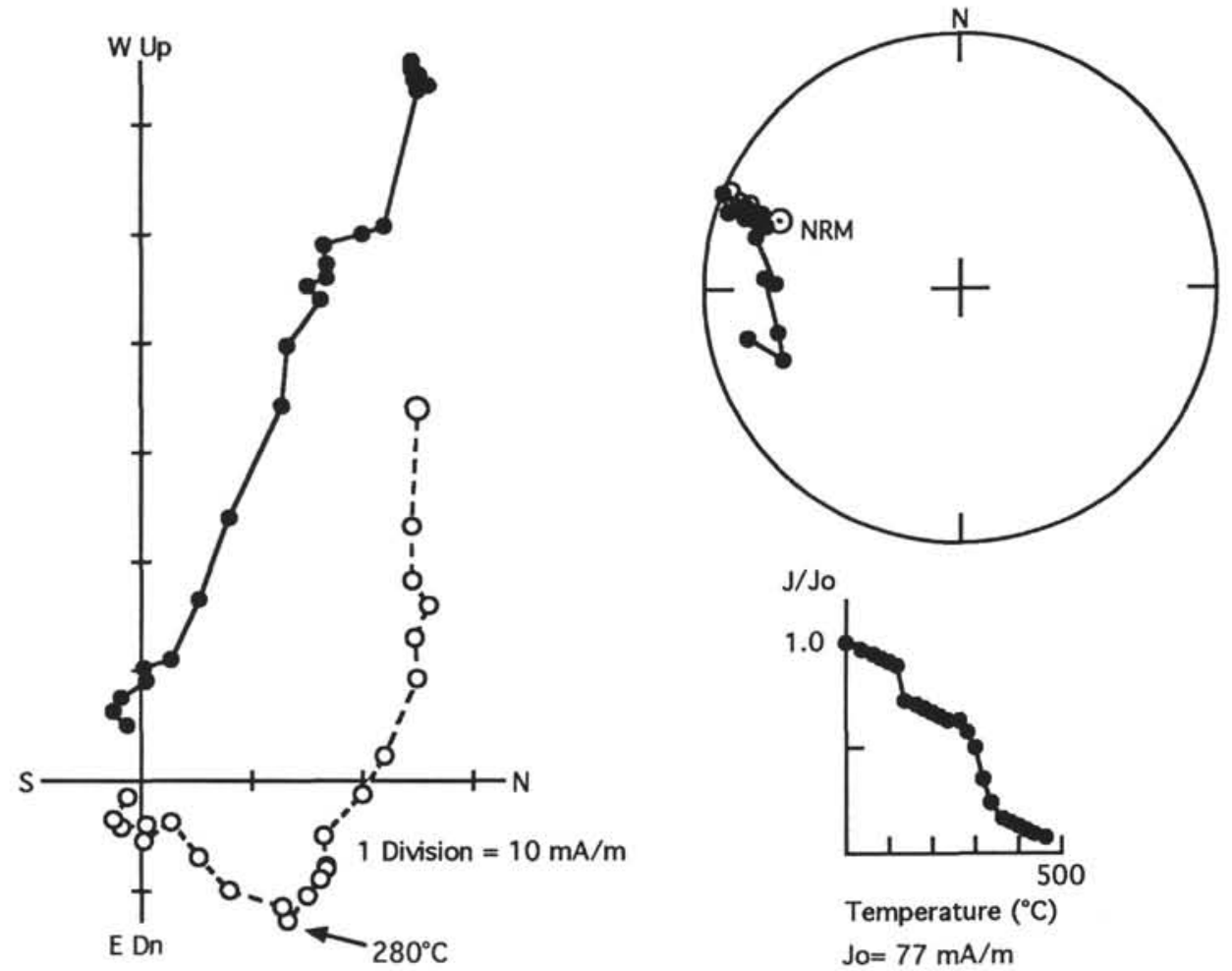

Figure 6. Zijderveld plot, Schmidt projection, and demagnetized intensity plot of Sample 141-859B-18R-5, 92-94 cm. Symbols and demagnetization intervals as for Figure 3. 
Other samples follow paths which are closer to reversible (Fig. 14). None of the samples show any inflection in either their heating or cooling curves at or near $300^{\circ} \mathrm{C}$, despite the prominence of an inflection at this temperature in almost all the thermal demagnetization of remanence curves.

The shallowest sample in the Curie Point study (Sample 141-861A$1 \mathrm{H}-3,54-56 \mathrm{~cm}$, representing a depth of $3.55 \mathrm{mbsf}$ ), has nearly fully reversible heating and cooling runs, and the Curie Point determined from both runs is almost identical. All other samples exhibited a higher apparent Curie Point temperature on the heating run than on the cooling run. The difference between the heating- and cooling-run Curie Points reached a maximum of nearly $10^{\circ} \mathrm{C}$ for Samples $141-861 \mathrm{C}$ $35 \mathrm{X}-2,120-122 \mathrm{~cm},\left(602^{\circ}\right.$ and $593^{\circ} \mathrm{C}$, respectively) and $-863 \mathrm{~B}-49 \mathrm{R}-$ $1,78-80 \mathrm{~cm},\left(585^{\circ}\right.$ and $575^{\circ} \mathrm{C}$, respectively). These two samples are also exceptional, in that their cooling curves lie at magnetizations at or below the heating curve. Such a difference in the apparent Curie Point on the heating and cooling runs could result from a lag between the temperature measured by the temperature sensor (a thermocouple in close contact with the aluminum foil wrapped around the sample) and the actual temperature of the sample. However, past experience with the Curie balance used in this study suggests that the difference in the measured and actual temperatures is substantially less than could explain the measured differences in heating and cooling Curie Points observed in this study (C. Hunt, pers. comm. 1993).

\section{INTERPRETATION}

\section{Magnetic Carriers}

The thermomagnetic determinations of Curie Points of about $580^{\circ} \mathrm{C}-590^{\circ} \mathrm{C}$ in the cooling runs of most samples suggests that the principal magnetic phase present is magnetite (Tarling, 1983). This phase appears to carry a primary magnetization, at least in the case of Site 859 where a magnetostratigraphy can be recognized. However, the persistent inflection in the thermal demagnetization of remanence at $300^{\circ} \mathrm{C}$ cannot be explained as a partial TRM overprint on this magnetite, as the uniform temperature-time conditions implied are inconsistent with the variety of tectonic settings represented by this set of sediments (accreted and deformed wedge, undeformed slope basin, and deposition on an isolated ridge). Instead, there must be a distinct magnetic carrier present that demagnetizes much more abruptly at temperatures above $300^{\circ} \mathrm{C}$ than below $300^{\circ} \mathrm{C}$. The presence of an additional phase other than magnetite is also indicated by the IRM study. Abrupt demagnetization above $300^{\circ} \mathrm{C}$ could signal the approach to the Curie Point of this phase. Titanomagnetites have a Curie Point that is dependent on their titanium content, and high-titanium titanomagnetites can have Curie Points in this temperature range (Tarling, 1983); however, it is unlikely that a population of titanomagnetite with such a consistent titanium content would be present throughout all the sequences in these sites, and titanomagnetites could not account for the fields above $0.2 \mathrm{~T}$ required for IRM saturation. Pyrrhotite has a Curie Point ranging from $325^{\circ} \mathrm{C}$ for the ferrimagnetic phase $\left(\mathrm{Fe}_{7} \mathrm{~S}_{8}\right)$ to around $320^{\circ} \mathrm{C}$ for mixes of the ferrimagnetic and antiferromagnetic $\left(\mathrm{Fe}_{9} \mathrm{~S}_{10}\right)$ phases (Zapletal, 1993). Mixes of ferrimagnetic and antiferromagnetic pyrrhotite remain unsaturated in applied fields of $1 \mathrm{~T}$, and so pyrrhotite could be responsible for both the $300^{\circ} \mathrm{C}$ inflection in the thermal demagnetization of remanence and the continued acquisition of IRM above $0.2 \mathrm{~T}$. However, the Curie Point curves show no indication of a phase with a Curie Point in this temperature range.

An alternative explanation is the presence of a component that decomposes on heating in air to $300^{\circ} \mathrm{C}$. Krs et al. (1990) noted that thermal demagnetization completely demagnetizes greigite, an iron sulfide with the composition $\mathrm{Fe}_{3} \mathrm{~S}_{4}$, by about $350^{\circ} \mathrm{C}$. Snowball (1991) reported an irreversible drop in magnetization of greigite produced from a mixture of Mohrs salt and sodium sulfide on heating in air above $320^{\circ} \mathrm{C}$; although Snowball attributed this to the temperature having exceeded the Curie Point of greigite, the fact that the behavior was irreversible on further cooling suggests that the greigite physically
Table 1. Hysteresis parameters for sediment samples from Leg 141.

\begin{tabular}{|c|c|c|c|}
\hline $\begin{array}{l}\text { Core, section, } \\
\text { interval }(\mathrm{cm})\end{array}$ & $\underset{(\mathrm{mT})}{\mathrm{H}_{\mathrm{c}}}$ & $\begin{array}{l}\mathrm{H}_{\mathrm{ar}} \\
(\mathrm{mT})\end{array}$ & $\mathrm{H}_{\mathrm{cr}} / \mathrm{H}_{\mathrm{c}}$ \\
\hline $\begin{array}{l}141-859 \mathrm{~A}- \\
3 \mathrm{H}-4,52-54 \\
18 \mathrm{C}-\mathrm{CC} .7-9\end{array}$ & $\begin{array}{l}15.37 \\
13.09\end{array}$ & $\begin{array}{l}42.60 \\
42.07\end{array}$ & $\begin{array}{l}2.77 \\
3.21\end{array}$ \\
\hline $\begin{array}{l}141-859 B- \\
21 R-3,122-124 \\
32 R-2.21-23\end{array}$ & $\begin{array}{r}5.43 \\
21.85\end{array}$ & $\begin{array}{l}25.97 \\
59.79\end{array}$ & $\begin{array}{l}4.78 \\
2.74\end{array}$ \\
\hline $\begin{array}{l}141-860 \mathrm{~B}- \\
2 \mathrm{H}-6.71-73 \\
16 \mathrm{X}-2.102-104 \\
48 \mathrm{X}-1.134-136 \\
62 \mathrm{X}-4,12-14\end{array}$ & $\begin{array}{r}38.41 \\
9.51 \\
11.89 \\
10.72\end{array}$ & $\begin{array}{l}92.61 \\
44.85 \\
37.30 \\
37.75\end{array}$ & $\begin{array}{l}2.41 \\
4.72 \\
3.14 \\
3.52\end{array}$ \\
\hline $\begin{array}{l}141-861 \mathrm{~A}- \\
1 \mathrm{H}-3,54-56\end{array}$ & 11.60 & 38.09 & 3,28 \\
\hline $\begin{array}{l}141-861 \mathrm{C}- \\
5 \mathrm{H}-7,113-115 \\
18 \mathrm{X}-4,40-42 \\
35 \mathrm{X}-2,120-122\end{array}$ & $\begin{array}{l}15.90 \\
14.70 \\
12.58\end{array}$ & $\begin{array}{l}43.6 \\
47.3 \\
38.07\end{array}$ & $\begin{array}{l}2.74 \\
3.22 \\
3.03\end{array}$ \\
\hline $\begin{array}{l}141-861 \mathrm{D}- \\
\quad 7 \mathrm{R}-2,48-50\end{array}$ & 12.20 & 4.3 .1 & 3.53 \\
\hline $\begin{array}{l}141-863 \mathrm{~A}- \\
3 \mathrm{H}-4,63-65 \\
25 \mathrm{X}-2.38-40 \\
29 \mathrm{X}-1.61-63\end{array}$ & $\begin{array}{r}6.22 \\
10.80 \\
9.04\end{array}$ & $\begin{array}{l}38.8 \\
40.1 \\
43.7\end{array}$ & $\begin{array}{l}6.24 \\
3.71 \\
4.83\end{array}$ \\
\hline $\begin{array}{l}141-863 \mathrm{~B}- \\
15 \mathrm{R}-1.60-62 \\
18 \mathrm{R}-4,23-25 \\
19 \mathrm{R}-2,96-98 \\
24 \mathrm{R}-2,18-20 \\
31 \mathrm{R}-2,85-87 \\
36 \mathrm{R}-2,82-84 \\
41 \mathrm{R}-3,20-22 \\
49 \mathrm{R}-1.78-80\end{array}$ & $\begin{array}{r}6.08 \\
10.80 \\
7.87 \\
3.99 \\
2.75 \\
3.77 \\
5.67 \\
3.43\end{array}$ & $\begin{array}{l}32.1 \\
36.3 \\
33.8 \\
30.9 \\
28.9 \\
28.3 \\
32.7 \\
25.7\end{array}$ & $\begin{array}{r}5.28 \\
3.36 \\
4.29 \\
7.74 \\
10.51 \\
7.51 \\
5.77 \\
7.49\end{array}$ \\
\hline
\end{tabular}

decomposed at this temperature. Other observations also suggest the decomposition of the greigite through oxidation at temperatures of about $300^{\circ} \mathrm{C}$ (R.L. Reynolds, pers. comm., 1991; Roberts and Turner, 1993; Musgrave et al., 1993). Continued heating of greigite in air above $400^{\circ}-450^{\circ} \mathrm{C}$ results in the generation of secondary magnetite, and eventually its further oxidation to hematite (R.L. Reynolds, pers. comm., 1991). Pyrrhotite also decomposes to secondary magnetite through oxidation during thermal demagnetization in air, but this has been reported to occur at temperatures above $400^{\circ} \mathrm{C}$ for pyrrhotite in marine sediments (Kobayashi and Nomura, 1972). Maghemite also decomposes on heating, converting to hematite at about $350^{\circ} \mathrm{C}$ (Tarling, 1983). Goethite is unstable in heating in air, and converts to poorly crystalline hematite at temperatures of about $200^{\circ}-290^{\circ} \mathrm{C}$ (Hedley, 1968), but goethite has a maximum Curie Point of about $120^{\circ} \mathrm{C}$ (Dekkers and Rochette, 1992), and so cannot be directly responsible for the demagnetization of remanence behavior at $300^{\circ} \mathrm{C}$. Neither maghemite nor goethite is likely to have been produced or survive in the reducing environment of the Leg 141 samples.

Curie Point studies did not indicate any significant reduction in susceptibility at $300^{\circ} \mathrm{C}$. These studies differed from the thermal demagnetization of remanence analyses in that they were conducted in a helium environment, with air having been removed from the samples by evacuation followed by He purging. Greigite has been reported to decompose during heating in vacuum, but this decomposition is substantially slower than its oxidation during heating in air: Skinner et al. (1964) found only a small proportion of greigite to decompose at $282^{\circ} \mathrm{C}$ over a 148 -hr run; other runs at $320^{\circ}$ and $295^{\circ} \mathrm{C}$ over 504 and $17 \mathrm{hr}$, respectively, showed complete decomposition of greigite. Curie Point analyses in the current study were conducted with heating rates of $20^{\circ} \mathrm{C} / \mathrm{min}$ (for a total heating and cooling cycle time of 45 to $60 \mathrm{~min}$ ), so it is probable that only a small proportion of any greigite present would have decomposed, leaving no clear evidence on the Curie Point curves.

The higher magnetization at the end of the cooling run compared with the magnetization at the same temperatures on the heating run in almost all samples implies that new magnetic phases were generated 

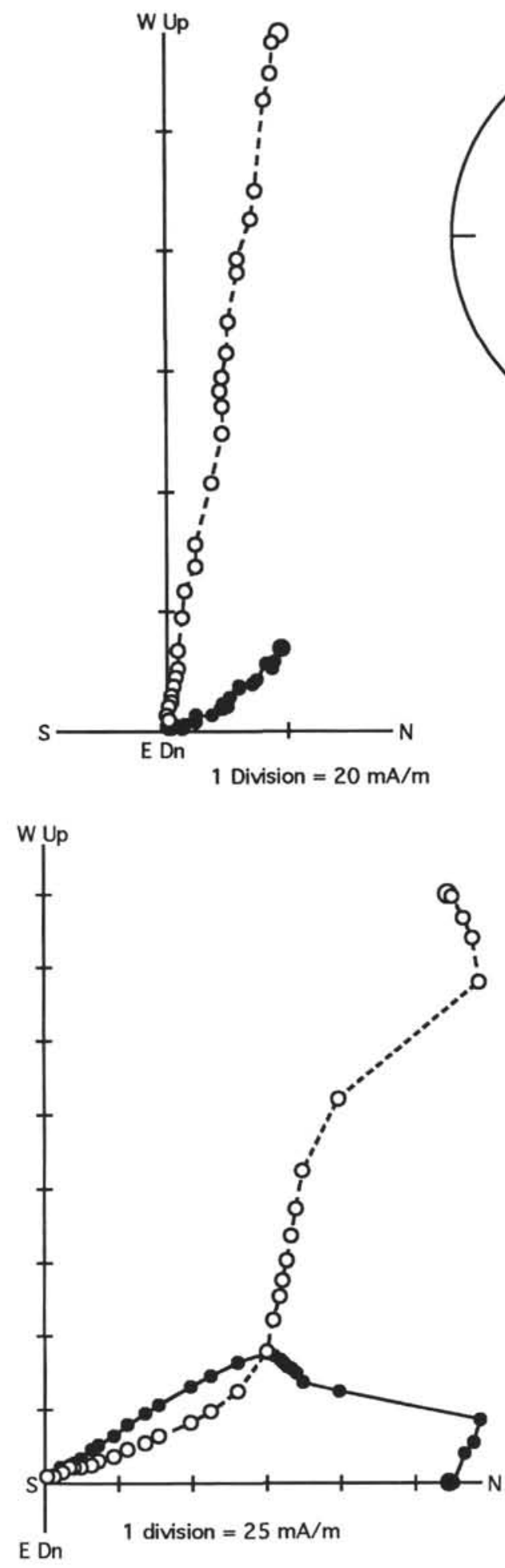
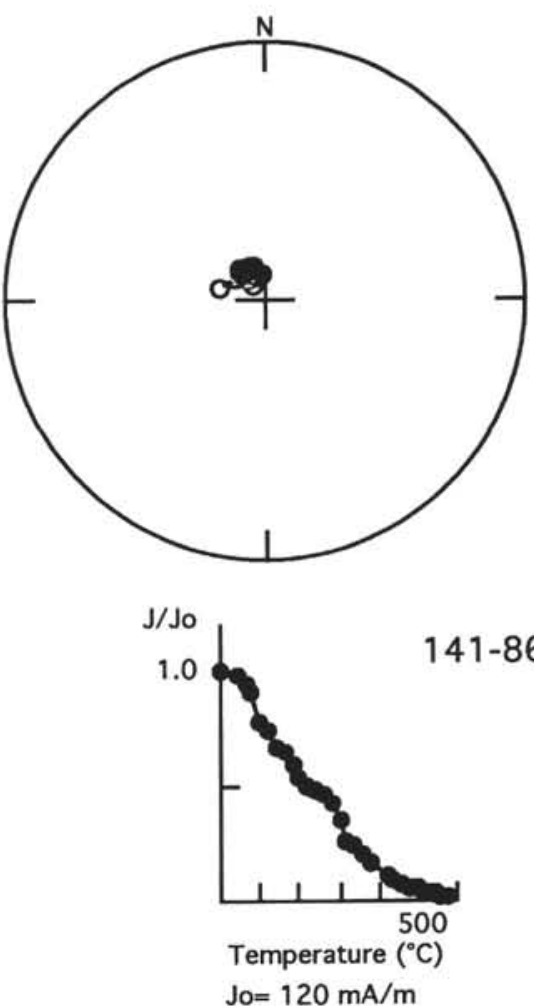

$141-862 \mathrm{~A}-3 \mathrm{H}-2,64-66 \mathrm{~cm}$

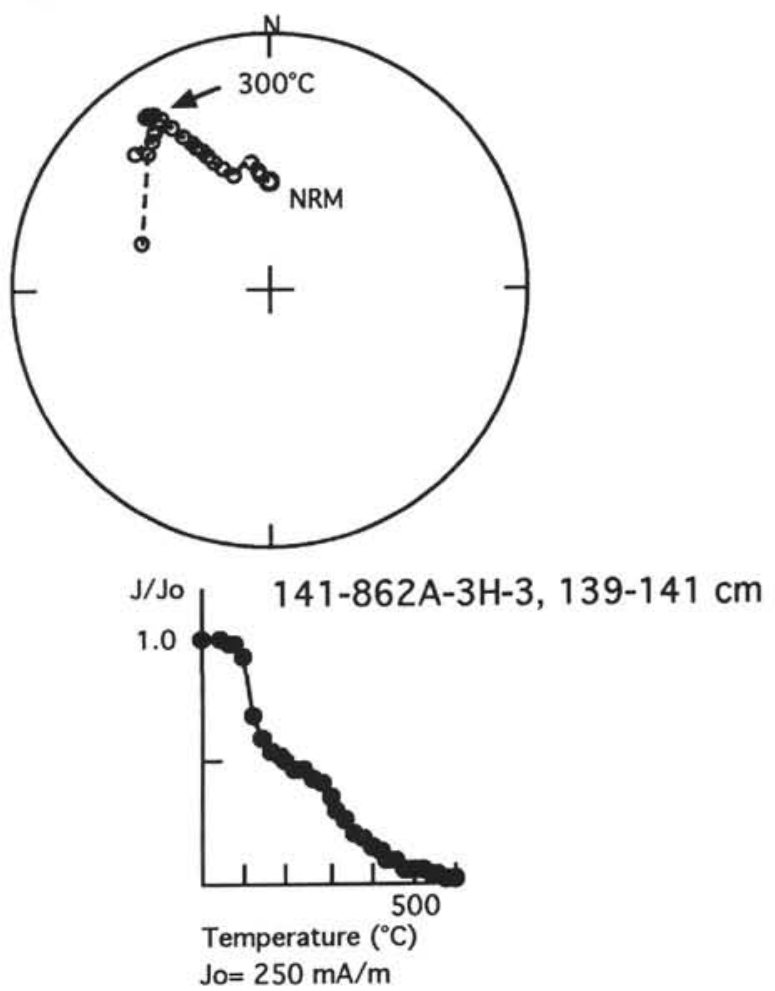

Figure 7. Zijderveld plot, Schmidt projection, and demagnetized intensity plot of samples from Core 141-862-3H. Symbols and demagnetization intervals as for Figure 3.

during heating. The increase in magnetization would be consistent with the generation of magnetite (spontaneous magnetization of 92 $\mathrm{Am}^{2} / \mathrm{kg}$; Tarling, 1983) from greigite (maximum spontaneous magnetization of $37.6 \mathrm{Am}^{2} / \mathrm{kg}$ reported by Spender et al., 1972) or from pyrrhotite (spontaneous magnetization of about $13.5 \mathrm{Am}^{2} / \mathrm{kg}$; Tarling, 1983), but inconsistent with the generation of hematite from mag- hemite, which involves a large decrease in spontaneous magnetization (Tarling, 1983). However, all three of these processes require oxygen. The increase in saturation magnetization may be better explained by the alteration of paramagnetic clay minerals.

Sample 141-863A-1H-3, 54-56 cm, which shows nearly reversible heating and cooling runs, evidently contains little or none of the 

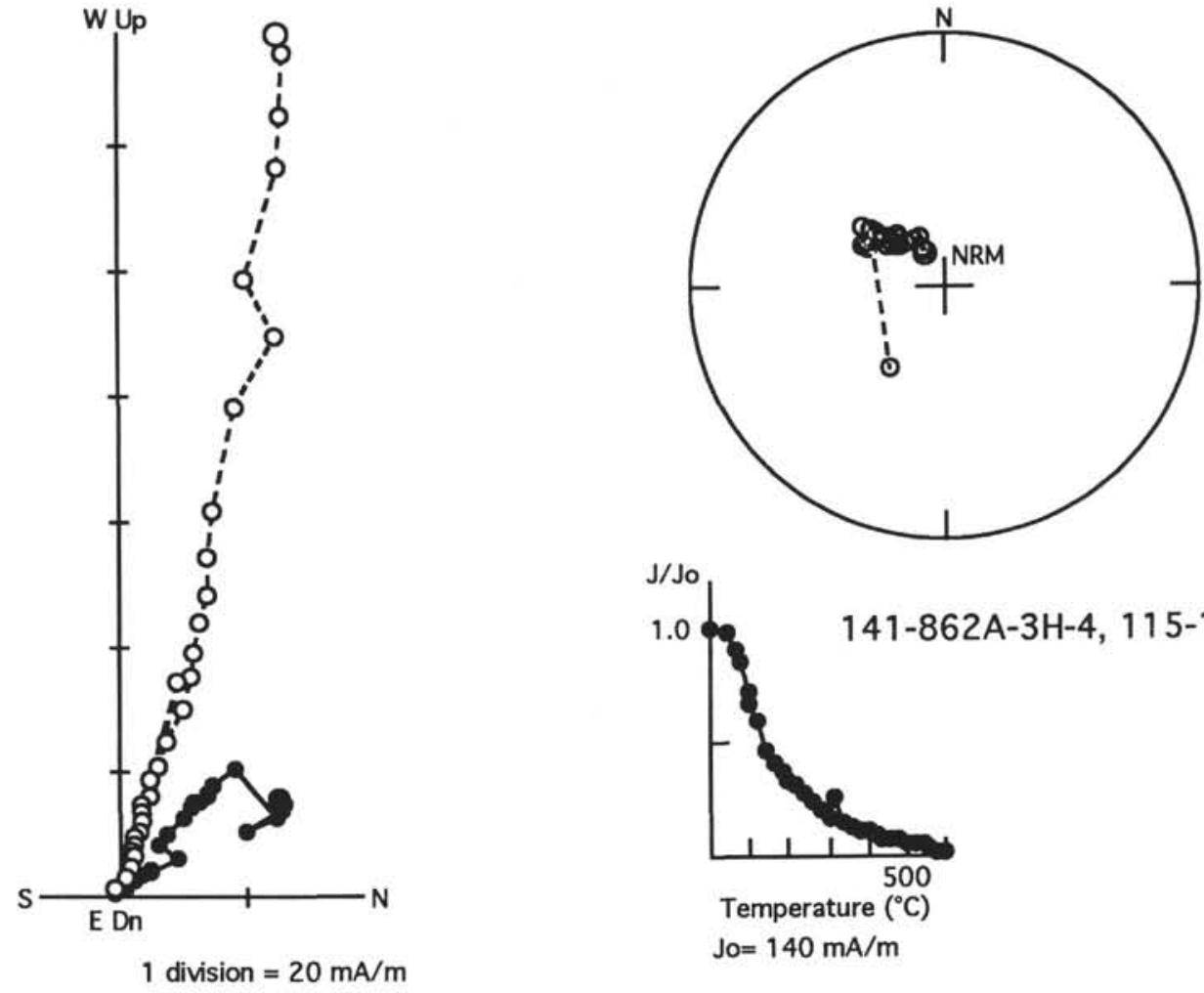

Figure 7 (continued).

unstable phase. The same is presumably true of Samples 141-861C$35 \mathrm{X}-2,120-122 \mathrm{~cm}$, and $-863 \mathrm{~B}-49 \mathrm{R}-1,78-80 \mathrm{~cm}$, that show nearly reversible behavior but an apparent offset in their heating and cooling Curie Points. If the offset in the Curie Points is real, it implies some alteration to a magnetic carrier during heating, but what alteration is involved is not clear.

Samples containing greigite have been reported to saturate in applied static fields of 0.1-0.2 T (Krs et al., 1992; Hoffmann, 1992). Roberts and Turner (1993) found that their greigite-bearing samples saturated in pulsed fields of 0.2-0.3 T. Kligfield and Channell (1988) found that remagnetized Helvetic limestones contained a magnetic carrier that required fields of 0.4-1.0 T for IRM saturation, and which showed similar resistance to $\mathrm{AF}$ demagnetization as that observed in the Leg 141 samples. Kligfield and Channell recognized the association of this carrier with biologically mediated pyritization, and suggested that the magnetic phase was pyrrhotite; they did not consider the possibility of greigite. Sager (1988) recognized an increase in the mean destructive alternating field required to demagnetize marine carbonates at sub-bottom depths below where magnetite dissolution was occurring; Sager attributed this to the generation of magnetic iron sulfides, and offered both pyrrhotite and greigite as candidates. Musgrave et al. (1993) reported both an increase in resistance to AF demagnetization and an increase in the applied field required for IRM saturation in similar circumstances in marine carbonates, and again attributed this to the generation of magnetic sulfides.

\section{Magnetic Grain Size}

Hysteresis of samples from Sites 859, 860, and 861, and from above 500 mbsf at Site 863 , suggests that the dominant magnetic carrier has a PSD grain size, with a trend towards an increasing proportion of MD grains. While there is evidence for two different magnetic phases, the thermomagnetic and thermal demagnetization of remanence behavior indicates that magnetite is the dominant phase.
The trend towards an increasing MD fraction could be explained by authigenic growth of either magnetite or a magnetic sulfide, or alternatively by the dissolution of magnetite, which would preferentially remove the smaller, PSD-sized fraction of an initial mix of PSD and MD magnetite.

The concave thermal demagnetization of remanence intensity behavior above $300^{\circ} \mathrm{C}$ of samples from Hole $863 \mathrm{~A}$ and from below 500 mbsf in Hole 863B is consistent with a reduced proportion of higher blocking-temperature magnetite, and is most easily explained by the preferential removal of fine-grained PSD magnetite grains from these samples. Sample 141-863B-46R-1, 99-101 cm, which has a more linear intensity plot above $300^{\circ} \mathrm{C}$, corresponds to the interval of reduced overprinting from 675 to 725 mbsf. Hysteresis of samples from below $500 \mathrm{mbsf}$ at Site 863 indicate both a further shift from PSD toward MD-sized grains, and a trend into the superparamagnetic field. An increase in the proportion of superparamagnetic magnetite would be inconsistent with dissolution of PSD-sized magnetite. A likely explanation for both trends below $500 \mathrm{mbsf}$ at Site 863 is the increased dissolution of magnetite, pushing the magnetite population toward the PSD field, coupled with a consequential increased growth of superparamagnetic-sized authigenic magnetic sulfide grains.

\section{Site 859}

It is possible that component D from Sample 141-859B-13R-3, $91-93 \mathrm{~cm}$, which is removed at about $200^{\circ} \mathrm{C}$, represents a magnetization carried by a thermally unstable magnetic phase. However, the lower temperature of this inflection suggests that it does not result from the decomposition of greigite, and the temperature involved does not match the expected temperature at which any of the other phases described above either decompose or reach their Curie Point. The absence of the characteristic $300^{\circ} \mathrm{C}$ inflection in this sample implies that the unstable phase which is present in most other samples is absent. Magnetite is the other phase present in most samples, and 


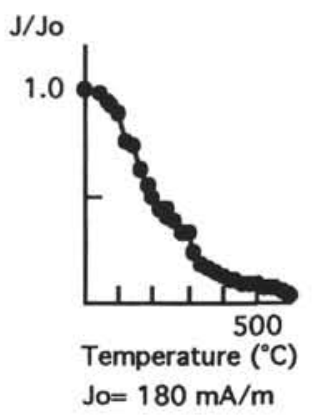

141-863A-1H-2, $29-31 \mathrm{~cm}$

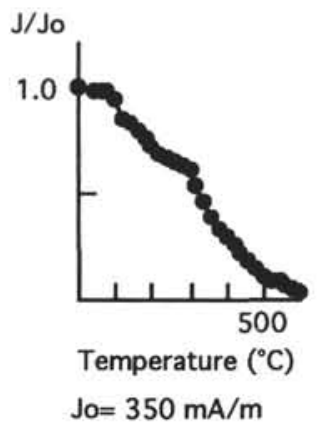

$141-863 \mathrm{~B}-7 \mathrm{~N}-2$, $33-35 \mathrm{~cm}$

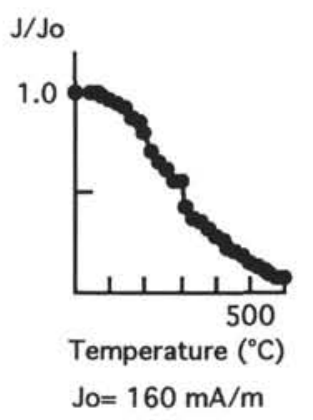

141-863B-2OR-1, $41-43 \mathrm{~cm}$

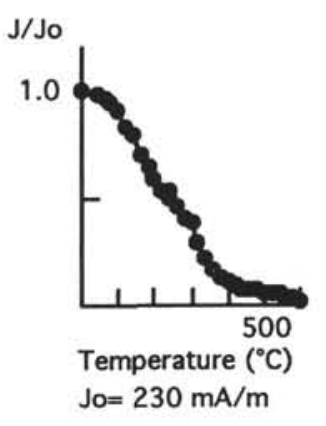

$141-863 \mathrm{~A}-5 \mathrm{H}-2$, $84-86 \mathrm{~cm}$

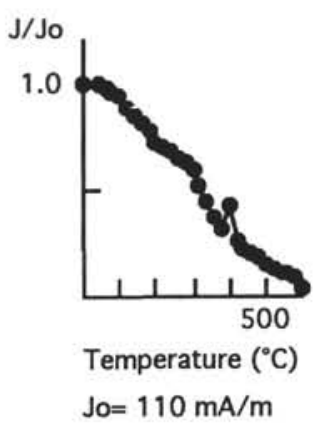

141-863B-13R-1, $55-57 \mathrm{~cm}$

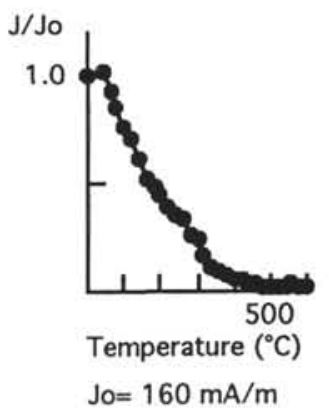

141-863B-21R-2, $37-39 \mathrm{~cm}$

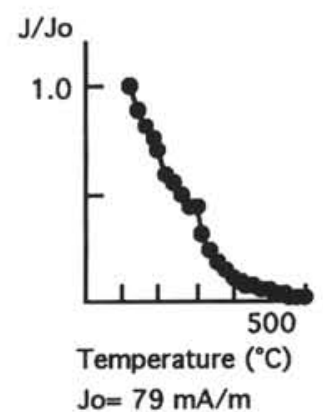

141-863A-30X-2, $51-53 \mathrm{~cm}$

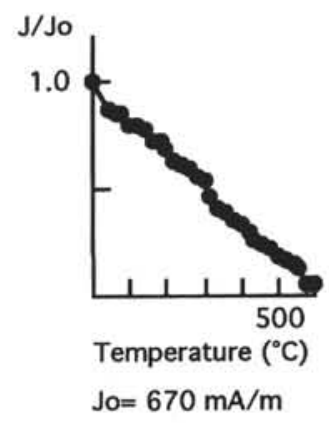

141-863B-18R-2, $80-82 \mathrm{~cm}$

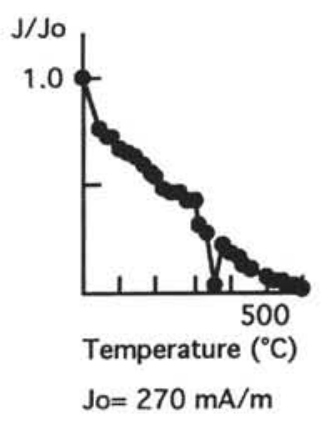

141-863B-23R-1, $47-49 \mathrm{~cm}$

Figure 8. Demagnetized intensity curves from Site 863.

component $\mathrm{D}$ may represent an overprint carried by magnetite. Hysteresis studies suggest that most samples from Site 859 are dominated by PSD grains. If this overprint arose as a partial thermal remanence, we can therefore calculate its acquisition time and temperature by reference to the relaxation time-temperature curve for magnetite (Fig. 15; Dunlop and Hale, 1977); assuming a laboratory blocking temperature of $200^{\circ} \mathrm{C}$ and relaxation time of $20 \mathrm{~min}$, we can predict an in-situ temperature of about $90^{\circ} \mathrm{C}$ for an acquisition time of 1000 $\mathrm{yr}$, about $100^{\circ} \mathrm{C}$ for an acquisition time of $100 \mathrm{yr}$, or about $120^{\circ} \mathrm{C}$ for an acquisition time of $10 \mathrm{yr}$. Similar acquisition temperatures and times can be interpreted for a partial thermoremanence in Samples 141-859B-1R-2, 38-40 cm, and 141-859B-14R-3, 77-79 cm, although the interpretation of thermal overprinting is more speculative, as the inflection at $200^{\circ} \mathrm{C}$ does not coincide with a magnetization component with a clearly distinguishable direction. Thermal overprinting may also be present in Sample 141-859B-33R-2, 64-66 cm, but the complexity of its demagnetization of remanence behavior makes interpretation still more speculative; however, the series of changes in direction of its demagnetization path may represent successive thermal overprints.

\section{DISCUSSION}

\section{Magnetic Sulfides}

Taken together, the thermal and AF demagnetization of remanence and the Curie balance, IRM, and hysteresis analysis all support the 


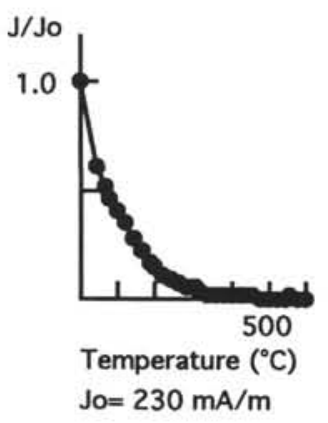

141-863B-26R-1, $31-33 \mathrm{~cm}$

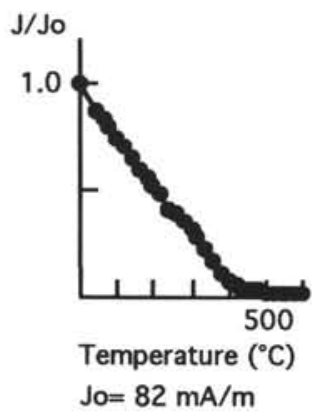

141-863B-48R-2, $23-25 \mathrm{~cm}$

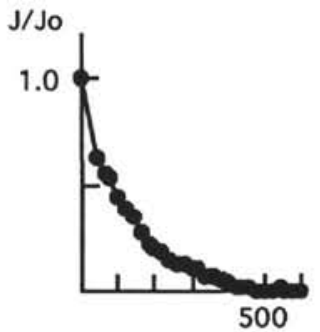

Temperature $\left({ }^{\circ} \mathrm{C}\right)$

$\mathrm{Jo}=57 \mathrm{~mA} / \mathrm{m}$

141-863B-35R-5, $17-19 \mathrm{~cm}$

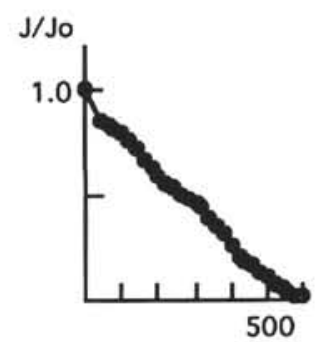

Temperature $\left({ }^{\circ} \mathrm{C}\right)$

$\mathrm{Jo}=130 \mathrm{~mA} / \mathrm{m}$

141-863B-46R-1, $99-101 \mathrm{~cm}$

Figure 8 (continued).

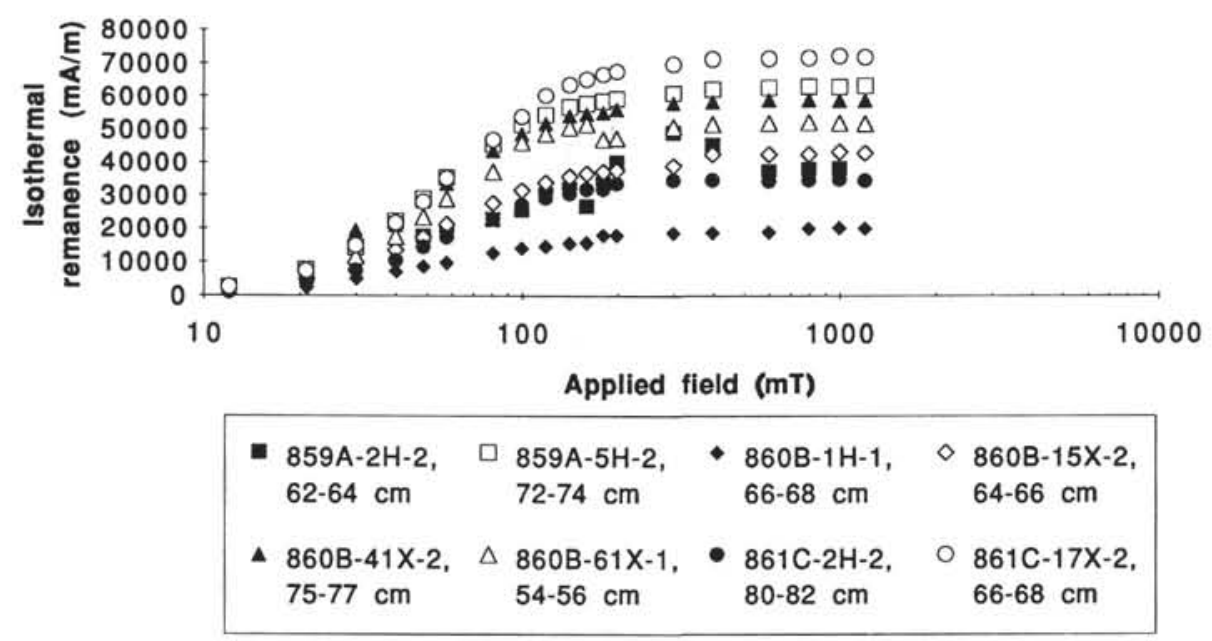

Figure 9. Examples of IRM acquisition curves for Leg 141 sediments. All samples are saturated by applied fields between 0.2 and 0.6 T.

presence of magnetic iron sulfides in most samples. No definite discrimination can be made between pyrrhotite and greigite; the loss of intensity at $300^{\circ} \mathrm{C}$ during heating in air and the lack of a corresponding Curie Point at about $300^{\circ} \mathrm{C}$ in the thermomagnetic curves during heating in the absence of oxygen support the presence of greigite rather than pyrrhotite, but the IRM behavior and resistance to $\mathrm{AF}$ demagnetization are more in accord with the behavior of pyrrhotite than with the available data on greigite.
The role of greigite as a magnetic phase in sediments has only recently been appreciated. It has been described as an authigenic component from a number of freshwater lake sediments (e.g., Snowball and Thomson, 1988, 1990; Hilton, 1990). Evidence for greigite from marine sediments is less common, but a magnetic iron sulfide in calcareous oozes, chalks, and limestones from the Ontong Java Plateau (Musgrave et al., 1993) was identified as greigite on the basis of its partial decomposition following exposure to air. The presence of 


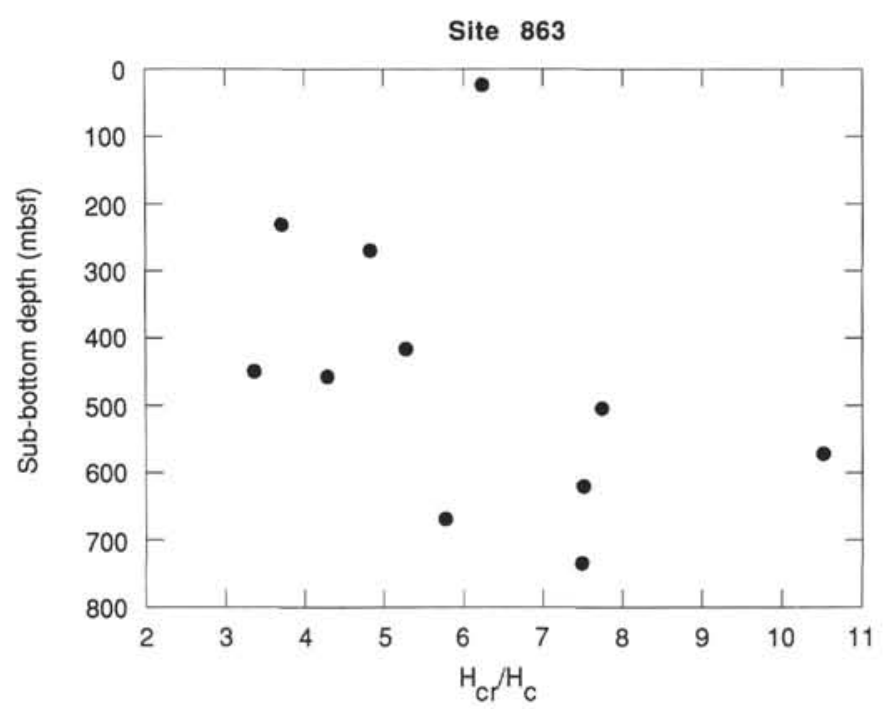

Figure $10 . \mathrm{H}_{\mathrm{cr}} / \mathrm{H}_{\mathrm{c}}$ vs. depth for Site 863 .

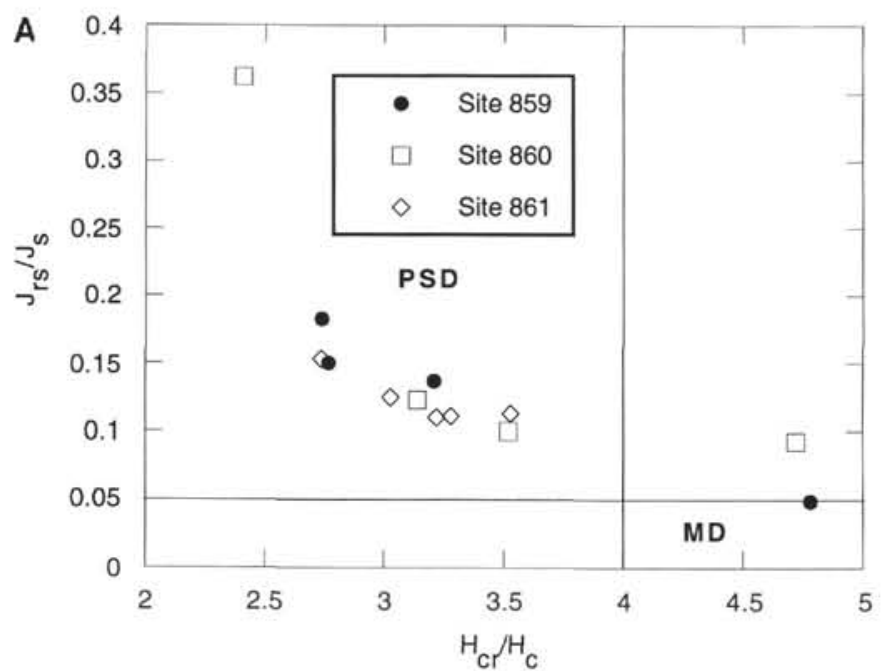

magnetic iron sulfides in the Ontong Java Plateau samples appears to be associated with the dissolution of fine-grained magnetite and was strongly controlled by the input of organic matter to the sediments.

Biogenic greigite, produced by magnetotactic bacteria from brackish to marine, sulfide-rich water, has been identified by Heywood et al. (1990) and Mann et al. (1990). Authigenic production of greigite within the sediment column, as an intermediate stage in a sequence involving reduction of iron oxides and sulfate and proceeding through initial biogenic generation of magnetite and subsequent dissolution of magnetite (Karlin and Levi, 1983, 1985; Karlin et al., 1987), through generation of greigite and proceeding to the production of pyrite (Schoonen and Barnes, 1991a, 1991b), has been described for the sequence from the Ontong Java Plateau (Musgrave et al., 1993). Although greigite is conventionally regarded as an intermediate step in the production of pyrite, and as thermodynamically unstable relative to pyrrhotite (Berner, 1967), it evidently survives where reduction conditions are suitable. Indeed, greigite was thought to be present in the Leg 130 sediments over a range of intensity of dissolution of magnetite and generation of pyrite. It may be that, as reduction continues to drive greigite toward pyrite, more greigite is generated in its place, so that at least some greigite can be expected to survive wherever unoxidized organic material and unreduced iron oxides persist.

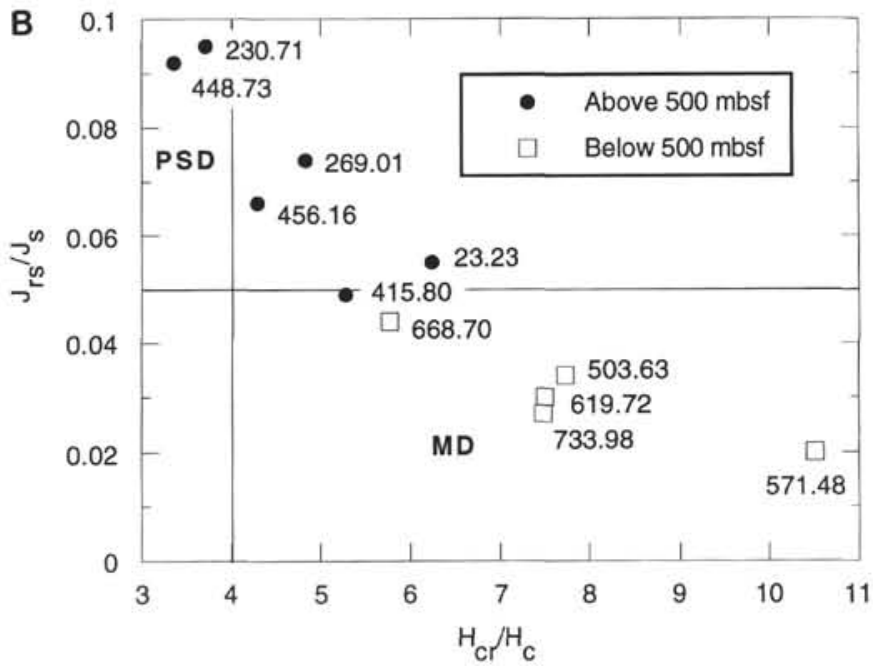

Figure 11. Plots of $\mathrm{J}_{\mathrm{rs}} / \mathrm{J}_{\mathrm{s}}$ vs. $\mathrm{H}_{\mathrm{cr}} / \mathrm{H}_{\mathrm{c}}$ for Leg 141 sediments, showing fields for populations of PSD and MD grains. A. Sites 859, 860, and 861. B. Site 863: depth of each sample in mbsf is indicated.
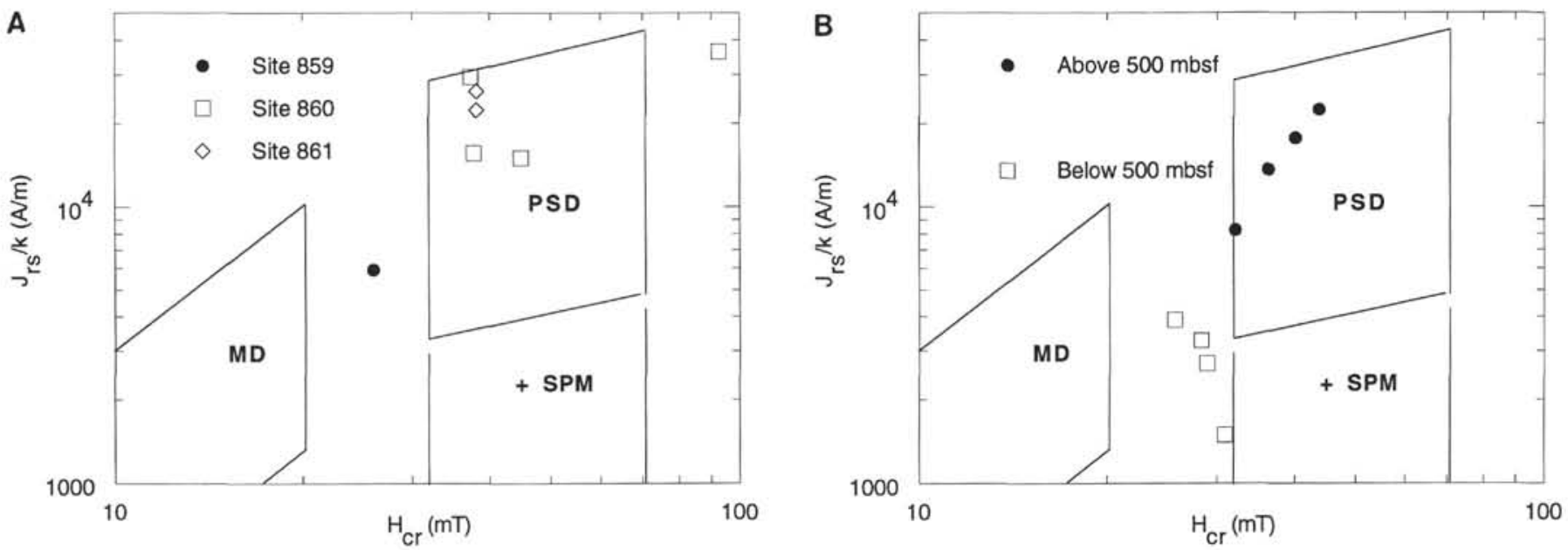

Figure 12. Plots of $\mathrm{J}_{\mathrm{rs}}$ normalized for volume susceptibility (in the SI definition) vs. $\mathrm{H}_{\mathrm{cr}}$. Fields for PSD and MD grains, and for mixed populations of PSD and superparamagnetic grains (+SPM). A. Sites 859,860 , and 861 . B. Site 863 . 
$141-859 B-32 R-2,21-23 \mathrm{~cm}$

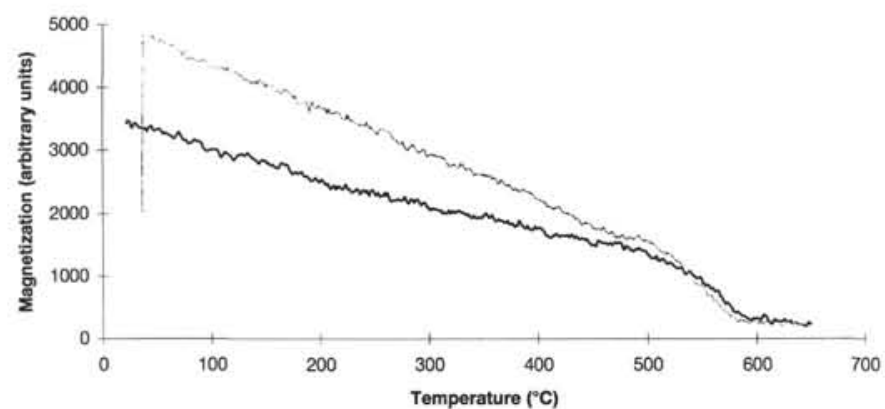

141-861D-7R-2, 48-50 cm

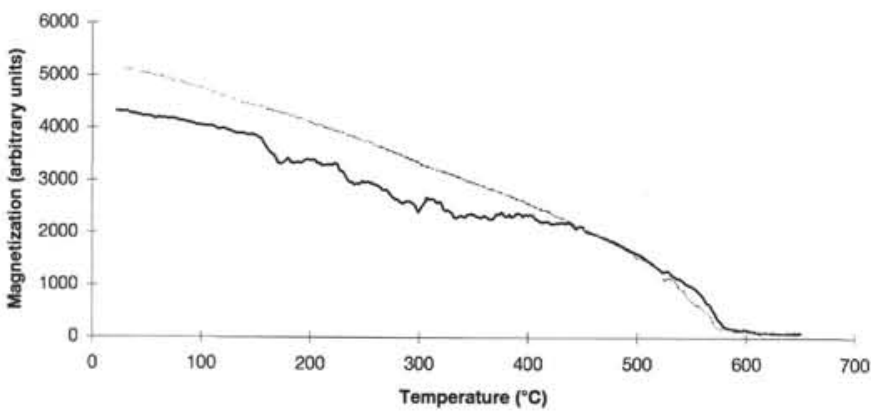

$141-860 \mathrm{~B}-16 \mathrm{X}-2,102-104 \mathrm{~cm}$

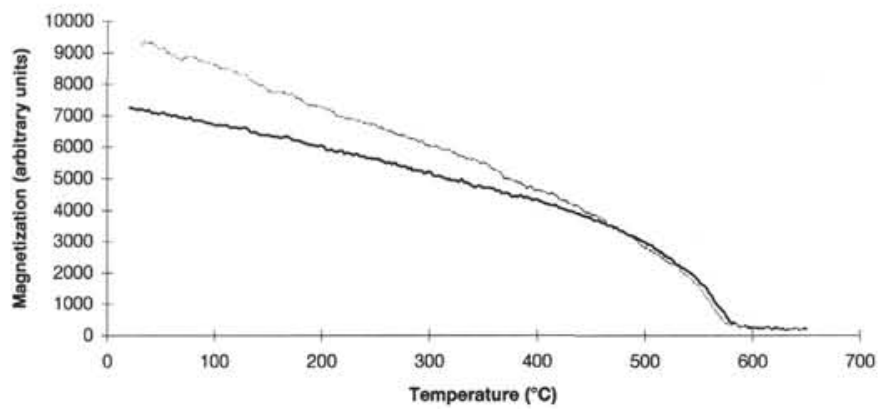

141-863A-3H-4, 63-65 cm

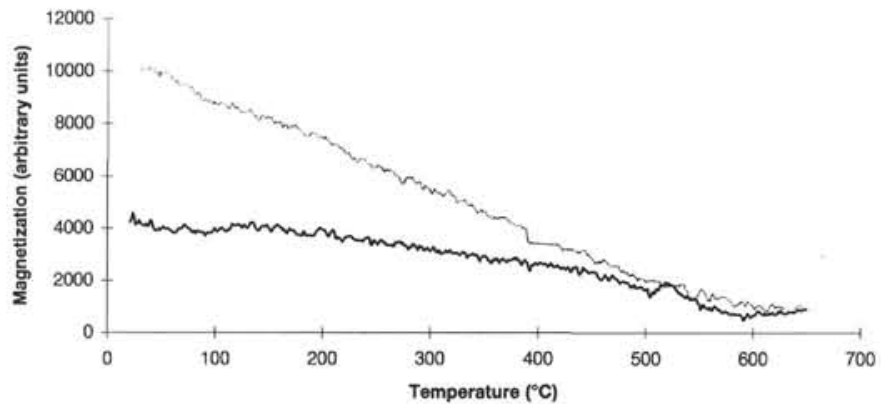

Figure 13. Examples of irreversible Curie Point runs. Heating run is shown by dark line, cooling run by light line.

$141-861 \mathrm{~A}-1 \mathrm{H}-3,54-56 \mathrm{~cm}$

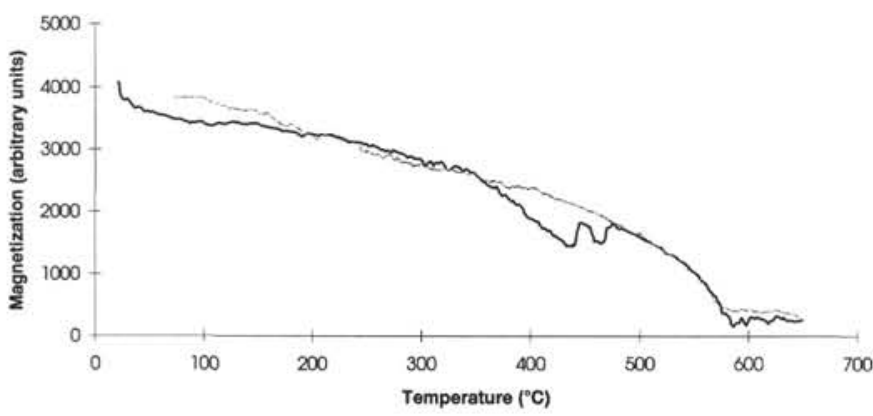

$141-861 \mathrm{C}-35 \mathrm{X}-2,120-122 \mathrm{~cm}$

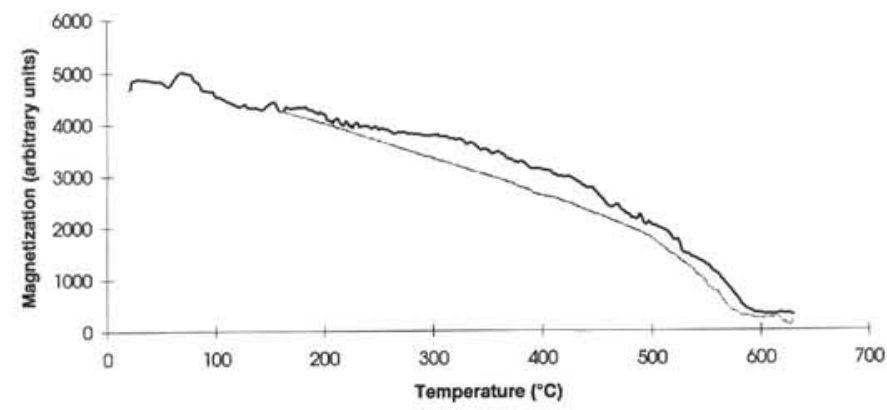

141-863B-49R-1, 78-80 cm

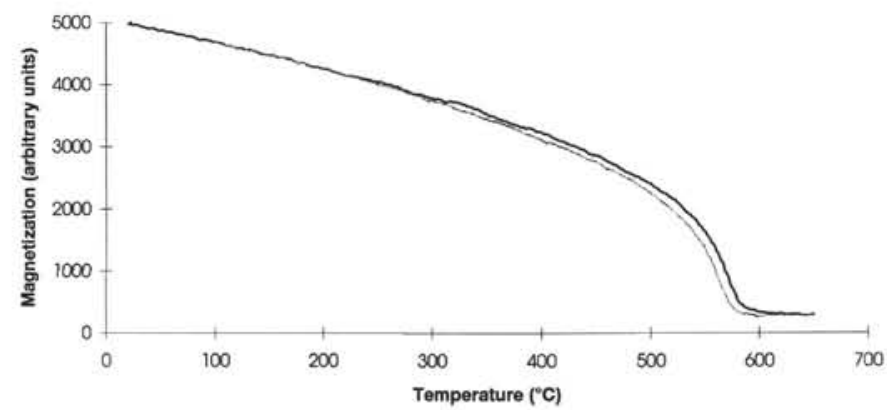

Figure 14. Examples of nearly reversible Curie Point runs. Heating run is shown by dark line, cooling run by light line. 


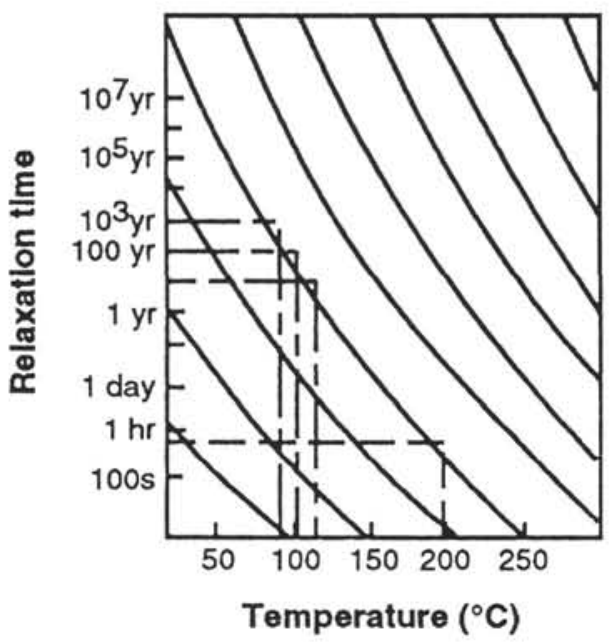

Figure 15. Relaxation time vs. temperature nomogram for SD/PSD magnetite (after Dunlop and Hale, 1977). The dashed lines indicate the temperaturerelaxation time conditions during laboratory unblocking, and some equivalent in-situ temperature-time conditions.

It is unclear whether bacteria are always explicitly involved in the process of generation of magnetic iron sulfides in marine sediments. However, scanning electron micrographs of Leg 141 samples indicate the presence of framboids of pyrite, commonly concentrated in fractures and "dark seams" within the "broken formation" (D. Prior, pers. comm., 1993). Individual spheroids within these framboids, with diameters of about $1 \mu \mathrm{m}$, are frequently amorphous to poorly crystalline; although the composition of these spheroids has not yet been determined, it seems likely that they are the sites of incomplete pyritization and survival of greigite. These spheroids are an order of magnitude larger than the individual greigite magnetosomes reported from magnetotactic bacteria (50-90 nm; Heywood et al., 1990), and it may be that they represent extracellular generation of magnetic iron sulfides by dissimilatory bacteria (similar to the extracellular bacterial production of magnetite; Lovley et al., 1987; Lovley and Phillips, 1988), with the spheroids representing a "ghost" of a former bacterium. Magnetic iron sulfides have been reported to be produced in this fashion by the sulfate-reducing bacterium Desulfovibrio desulfuricans (Moskowitz et al., 1993). The size of individual grains within the framboids is not clear; however, extracellular magnetite is reported to range from approximately $10 \mathrm{~nm}$ to about $50 \mathrm{~nm}$ (Lovley et al., 1987). If the framboids of magnetic iron sulfides have a similar origin and grain size, then the individual grains within them are likely to be superparamagnetic, in accord with the hysteresis results from Site 863 indicating a trend towards the superparamagnetic field with increased magnetite dissolution and (presumably) increased magnetic sulfide generation.

Pyrite was described not only as concentrations within fractures and dark seams, but also scattered throughout many cores in all holes. Pods and smears of amorphous black material, typically associated with burrows and thought to include both organic material and pyrite, were described in Cores 141-861 A-1H, $-861 \mathrm{~B}-1 \mathrm{H}$ and $-861 \mathrm{C}-1 \mathrm{H}$, and at Site 863 throughout Subunit IA ( $0-46.6 \mathrm{mbsf})$ and extending down into Subunit IB (Behrmann, Lewis, Musgrave, et al., 1992), which corresponds to a zone of intense overprinting and resistance to $\mathrm{AF}$ demagnetization. Magnetic iron sulfides may arise through in-situ alteration of these organic materials, or of similar organic material distributed through the cores. Concentrations of magnetic iron sulfides and pyrite in fractures and dark seams, however, indicate the remobilization of organic materials. Given the evidence for the mobility of methane and higher hydrocarbons in the accretionary wedge sediments from this leg (see "Organic Geochemistry" section in the chapters for Sites $859,860,861$, and 863 in Behrmann, Lewis, Musgrave, et al., 1992), it is likely that the "feedstocks" for bacterial production of greigite in these fractures and seams are hydrocarbons migrating via the fractures. Sulfur in these fractures, and in other occurrences of greigite below the base of the sulfate-reduction zone, presumably comes from $\mathrm{H}_{2} \mathrm{~S}$; this gas may also make its way along fractures and dark seams.

\section{Thermal Overprinting at Site 859}

Thermal overprinting in Sample 141-859B-13R-3, 91-93 cm, which comes from a depth of 228.3 mbsf, suggests a past history of hot-water flow at Site 859 similar to the currently active hot-water conduit indicated by the WSTP results at 245 mbsf. Note that the thermally overprinted sample occurs closer to one of the anomalously low-temperature points recorded by the WSTP than to the point marking the current position of the "hot jet." Evidently the conduit of heated water has migrated in the past within the hypothesized zone of fracturing between about 215 and 260 mbsf, which is marked by the current low-temperature anomaly and chemical discontinuities (Shipboard Scientific Party, 1992b). The temperature-relaxation time analysis suggests that the temperature of the water involved in the past thermal event at $228 \mathrm{mbsf}$ had to be higher than the temperature of $43^{\circ} \mathrm{C}$ directly estimated from the WSTP results for the currently active jet. This supports the tentative shipboard interpretation that the actual temperature of the currently active jet is substantially higher than $61^{\circ} \mathrm{C}$. The narrow vertical extent of the current high temperature anomaly suggests a short lifetime for the hot-water conduit involved; estimates of $100^{\circ} \mathrm{C}$ for $90 \mathrm{yr}, 90^{\circ} \mathrm{C}$ for $1000 \mathrm{yr}$, or $120^{\circ} \mathrm{C}$ for $10 \mathrm{yr}$, for the temperature and lifetime of the earlier hot-water conduit near 228 mbsf are consistent with this interpretation. The more dubious evidence for thermal overprinting in Samples 141-859B-1R-2, 38-40 $\mathrm{cm}$, and 141-859B-14R-3, 77-79 cm, and possibly in Sample 141$859 \mathrm{~B}-33 \mathrm{R}-2,64-66 \mathrm{~cm}$, may suggest that the past flow of hot fluids has extended upward into the folded domain of Subunit IA and downward into the broken formation.

\section{Fluid Flow in the Vertically Bedded Sequence at Site 863}

The hysteresis and thermal and AF demagnetization behavior of the interval below 500 mbsf indicate a reduction in the proportion of PSD-sized magnetite and an increased proportion of superparamagnetic-sized grains of magnetic iron sulfides. AF demagnetization between 450 and 500 mbsf suggests transitional behavior that may mark a gradual decrease upward in dissolution of magnetite, whereas thermal demagnetization of remanence of samples from the interval of decreased overprinting between 675 and 725 mbsf also confirms reduced magnetite dissolution in this short interval. The interval below 405 mbsf (lithostratigraphic Subunit IIC) coincides with a zone of diagenetic alteration of clay to smectite; recrystallization of nannofossils; cementation and vein infilling by carbonate, zeolites, clay, and pyrite; and a high concentration of gasoline-range hydrocarbons. Inorganic geochemical evidence from the interval below $500 \mathrm{mbsf}$ suggests that in the past fluids from a source at a greater depth flowed vertically through this interval, whereas the interval from 400 to 500 mbsf was interpreted as either a diagenetic front or a zone of current lateral fluid flow (Shipboard Scientific Party, 1992d). Fluid flow may have been aided by the near-vertical bedding, allowing the sand units to act as extremely efficient conduits until cementation reduced their permeability. The cementation mineralogy and the presence of gasoline-range hydrocarbons suggest that the fluids involved were anomalously warm.

Introduction of additional hydrocarbons and $\mathrm{H} 2 \mathrm{~S}$ via the fluids flowing through this interval would have driven the magnetitegreigite/pyrrhotite-pyrite reaction further toward pyrite, thereby increasing the reduction of magnetite, and so increasing the selective dissolution of fine-grained, PSD magnetite. Insufficient $\mathrm{H}_{2} \mathrm{~S}$ and/or methane was apparently available to drive the reduction completely to pyrite, and so both coarse-grained magnetite and magnetic iron sulfides survived. 


\section{Site 862 Thermal History, Polarity, and Structural Orientation}

Despite the complex AF demagnetization of samples from Core $141-862 \mathrm{~A}-3 \mathrm{H}$, there is no evidence for thermal overprinting in the thermal demagnetization of remanence of the three samples from this core. Hydrothermal activity, if present locally, was apparently limited to the zone of obvious sediment pigmentation, or was at temperatures sufficiently low that any partial thermal remanence acquired has since relaxed.

All three samples from Core 141-862A-3H reveal a normally polarized characteristic magnetization, which appears to be primary. $\mathrm{AF}$ demagnetization of Cores $141-862 \mathrm{~A}-1 \mathrm{H}$ and $-2 \mathrm{H}$ also appears to indicate a normally polarized characteristic remanence. This is surprising, given the assignment of Core $141-862 \mathrm{~A}-3 \mathrm{H}$ to nannofossil Zones NN16-18, in the upper Pliocene, and Core 141-862A-1H to the RN13-16 radiolarian Zones and Truncorotalia truncatulinoides foraminifer zone, both representing the Pleistocene. If sedimentation was continuous, we would expect to have detected intervals of reversed polarity. Either sedimentation was markedly non-continuous, or the paleontological age assignments are in error.

The direction of the ChRM in Sample 141-862A-3H-2, 64-66 cm, is well defined $\left(\right.$ declination $=309^{\circ}$, inclination $=-80^{\circ}$ ), and can be used to orient the structural features recorded near this sample. Bedding at $141-862 \mathrm{~A}-3 \mathrm{H}-2,23-26 \mathrm{~cm}$, has a strike of $033^{\circ}$ and a dip of $31^{\circ} \mathrm{E}$ in the structural coordinate system (i.e., with a declination referred to a direction $180^{\circ}$ from the paleomagnetic reference orientation; see Shipboard Scientific Party, 1992a, 1992c). Rotating the bedding back to the horizontal restores the ChRM to declination = $300^{\circ}$, inclination $=-69^{\circ}$, in the structural coordinate system. This in turn implies that the azimuth of the bedding dip at Sample 141-862A$3 \mathrm{H}-2,23-26 \mathrm{~cm}$, is toward $193^{\circ}$ in geographic coordinates, if we assume no net rotation of Site 862 around a vertical axis. Similarly, normal faults in this part of the sequence can be oriented in geographic coordinates; the fault at $141-862 \mathrm{~A}-3 \mathrm{H}-2,70-75 \mathrm{~cm}$, dips toward $304^{\circ}$, and the fault at $141-862 \mathrm{~A}-3 \mathrm{H}-2,112-117 \mathrm{~cm}$, dips toward $349^{\circ}$. These orientations are consistent with development of the structures at Site 862 in response to gravitational sliding on the topographic slope of Taitao Ridge, which locally dips steeply (about $30^{\circ}$ ) to the north-northwest, and which strikes subparallel to the Taitao Fracture Zone (Shipboard Scientific Party, 1992c). The alternative proposition, that the structures developed in response to seafloor spreading (implying on-axis development of Taitao Ridge), would require that the faults strike roughly north-south. However, this possibility cannot be completely ruled out, as rotation of Taitao Ridge around a vertical axis (which cannot be detected by the orientation procedure used above) could have occurred during emplacement in the forearc.

\section{ACKNOWLEDGMENTS}

We wish to express our appreciation for the dedicated efforts of the SEDCO and Schlumberger shipboard crews and the ODP Marine Technicians of Leg 141, and especially to thank the paleomagnetics technician, Monica Sweitzer. We also wish to thank our fellow members of the Shipboard Scientific Party for their observations and contributions: in particular, we wish to acknowledge Dave Prior's observations of the distribution and structure of sulfides in the sediments. Analytical work at the Institute for Rock Magnetism in Minneapolis was conducted by Margaret Hastedt, and we thank her for her enthusiasm and skill. Dean Merrill assisted with operation of the Texas A\&M University paleomagnetics laboratory. Mary Aikins and Darrell Williams conducted many of the thermal demagnetization of remanence and IRM measurements at Texas A\&M. Bernard Housen contributed many constructive comments regarding rock magnetic methodology. The text also benefitted from suggestions from three anonymous reviewers. We wish to thank the Geophysics Department of Texas A\&M University and the Institute for Rock Magnetism for the use of their facilities. The Institute for Rock Magnetism is funded by the Keck Foundation, the National Science Foundation, and the University of Minnesota. Robert Musgrave thanks the JOI U.S. Science Advisory Committee for grant support.

\section{REFERENCES}

Arason, P., and Levi, S., 1990. Models of inclination shallowing during sediment compaction. J. Geophys. Res., 95:4481-4500.

Bangs, N., Cande, S.C., Lewis, S.D., and Miller, J., 1992. Structural framework of the Chile Margin at the Chile Ridge collision zone. In Behrmann, J.H., Lewis, S.D., Musgrave, R.J., et al., Proc. ODP, Init. Repts., 141: College Station, TX (Ocean Drilling Program), 11-21.

Barton, C.E., and Bloemendal, J., 1986. Paleomagnetism of sediments collected during Leg 90, Southwest Pacific. In Kennett, J.P., von der Borch, C.C., et al., Init. Repts. DSDP, 90: Washington (U.S. Govt. Printing Office), 1273-1316.

Behrmann, J.H., Lewis, S.D., Musgrave, R.J., et al., 1992. Proc. ODP, Init. Repts., 141: College Station, TX (Ocean Drilling Program).

Berner, R.A., 1967. Thermodynamic stability of sedimentary iron sulphides. Am. J. Sci., 265:777-785.

Bleil, U., 1989. Magnetostratigraphy of Neogene and Quaternary sediment series from the Norwegian Sea: Ocean Drilling Program, Leg 104. In Eldholm, O., Thiede, J., Taylor, E., et al., Proc. ODP, Sci. Results, 104: College Station, TX (Ocean Drilling Program), 829-901.

Bradshaw, R.H.W., and Thompson, R., 1985. The use of magnetic measurements to investigate the mineralogy of some Icelandic lake sediments and to study catchment processes. Boreas, 14:203-215.

Day, R., Fuller, M.D., and Schmidt, V.A., 1977. Hysteresis properties of titanomagnetites: grain-size and compositional dependence. Phys. Earth Planet. Inter., 13:260-267.

Deamer, G.A., and Kodama, K.P., 1990. Compaction-induced inclination shallowing in synthetic and natural clay-rich sediments. J. Geophys. Res., 95:4511-4530.

Dekkers, M.J., and Rochette, P., 1992. Magnetic properties of chemical remanent magnetization in synthetic and natural goethite: prospects for a natural remanent magnetization/thermoremanent magnetization ratio paleomagnetic stability test? J. Geophys. Res., 97:17291-17307.

Dunlop, D.J., and Hale, C.J., 1977. Simulation of long-term changes in the magnetic signal of the oceanic crust. Can. J. Earth Sci., 14:716-744.

Hall, S.A., and Sager, W.W., 1990. Paleomagnetic and rock magnetic properties of sediment samples from Ocean Drilling Program Leg 116, central Indian Ocean. In Cochran, J.R., Stow, D.A.V., et al., Proc. ODP, Sci. Results, 116: College Station, TX (Ocean Drilling Program), 337-344.

Hedley, I.G., 1968. Chemical remanent magnetization of the $\mathrm{FeOOH}, \mathrm{Fe}_{2} \mathrm{O}_{3}$ system. Phys. Earth Planet. Inter, 1:103-121.

Heywood, B.R., Bazylinski, D.A., Garratt-Reed, A., Mann, S., and Frankel, R.B., 1990. Controlled biosynthesis of greigite $\left(\mathrm{Fe}_{3} \mathrm{~S}_{4}\right)$ in magnetotactic bacteria. Naturwissenschaften, 77:536-538.

Hilton, J., 1990. Greigite and the magnetic properties of sediments. Limnol. Oceanogr., 35:497-508.

Hoffmann, V., 1992. Greigite $\left(\mathrm{Fe}_{3} \mathrm{~S}_{4}\right)$ : magnetic properties and first domain observations. Phys. Earth Planet. Inter., 70:288-301.

Hounslow, M.W., Bootes, P.A., and Whyman, G., 1990. Remanent magnetization of sediments undergoing deformation in the Barbados accretionary prism: ODP Leg 110. In Moore, J.C., Mascle, A., et al., Proc. ODP, Sci. Results, 110: College Station, TX (Ocean Drilling Program), 379-391.

Karlin, R., and Levi, S., 1983. Diagenesis of magnetic minerals in Recent hemipelagic sediments. Nature, 303:327-330.

1985. Geochemical and sedimentological control of the magnetic properties of hemipelagic sediments. J. Geophys Res., 90:10373-10392.

Karlin, R., Lyle, M., and Heath, G.R., 1987. Authigenic magnetite formation in suboxic marine sediments. Nature, 326:490-493.

Kligfield, R., and Channell, J.E.T., 1981. Widespread remagnetization of Helvetic Limestones. J. Geophys. Res., 86:1888-1900.

Kobayashi, K., and Nomura, M., 1972. Iron sulfides in the sediment cores from the Sea of Japan and their geophysical implications. Earth Planet. Sci. Lett., 16:200-208.

\footnotetext{
Abbreviations for names of organizations and publications in ODP reference lists follow the style given in Chemical Abstracts Service Source Index (published by American Chemical Society).
} 
Kroenke, L.W., Berger, W.H., Janecek T.R., et al., 1991. Proc. ODP, Init. Repts., 130: College Station, TX (Ocean Drilling Program).

Krs, M., Krsová, M., Pruner, P., Zeman, A., Novák, F., and Jansa, J., 1990. A petromagnetic study of Miocene rocks bearing micro-organic material and the magnetic mineral greigite (Sokolov and Cheb basins, Czechoslovakia). Phys. Earth Planet. Inter., 63:98-112.

Krs, M., Novák, F., Krsová, M., Pruner, P., Kouklíková, L., and Jansa, J., 1992. Magnetic properties and metastability of greigite-smythite mineralization in brown-coal basins of the Krusné hory Piedmont, Bohemia. Phys. Earth Planet. Inter., 70:273-287.

Lovley, D., and Phillips, E.J.P., 1988. Novel mode of microbial energy metabolism: organic carbon oxidation coupled to dissimilatory reduction of iron or manganese. Appl. Environ. Microbiol., 54:1472-1480.

Lovley, D.R., Stolz, J.F., Nord, G.L., Jr., and Phillips, E.J.P., 1987. Anaerobic production of magnetite by a dissimilatory iron-reducing microorganism. Nature, 330:252-254.

Mann, S., Sparks, N.H.C., Frankel, R.B., Bazylinski, D.A., and Jannasch, H.W., 1990. Biomineralization of ferrimagnetic greigite $\left(\mathrm{Fe}_{3} \mathrm{~S}_{4}\right)$ and iron pyrite $\left(\mathrm{FeS}_{2}\right)$ in a magnetotactic bacterium. Nature, 343:258-261.

Moskowitz, B.M., Frankel, R.B., and Bazylinski, D.A., 1993. Rock magnetic criteria for the detection of biogenic magnetite. Earth Planet. Sci. Lett. 120:283-300.

Musgrave, R.J., Delaney, M.L., Stax, R., and Tarduno, J.A., 1993. Magnetic diagenesis, organic input, interstitial water chemistry, and paleomagnetic record of the carbonate sequence on the Ontong Java Plateau. In Berger, W.H., Kroenke, L.W., Mayer, L.A., et al., Proc. ODP, Sci. Results, 130: College Station, TX (Ocean Drilling Program), 527-546.

Roberts, A.P., and Turner, G.M., 1993. Diagenetic formation of ferrimagnetic iron sulphide minerals in rapidly deposited marine sediments, South Island, New Zealand. Earth Planet. Sci. Lett., 115:257-273.

Sager, W.W., 1988. Paleomagnetism of Ocean Drilling Program Leg 101 sediments: magnetostratigraphy, magnetic diagenesis, and paleolatitudes. In Austin, J.A., Jr., Schlager, W., et al., Proc. ODP, Sci. Results, 101: College Station, TX (Ocean Drilling Program), 327-360.

Schoonen, M.A.A., and Barnes, H.L., 1991a. Reactions forming pyrite and marcasite from solution, I. Nucleation of $\mathrm{FeS}_{2}$ below $100^{\circ} \mathrm{C}$. Geochim. Cosmochim. Acta, 55:1495-1504.

1991b. Reactions forming pyrite and marcasite from solution, II. Via FeS precursors below $100^{\circ} \mathrm{C}$. Geochim. Cosmochim. Acta, 55:15051514.

Shipboard Scientific Party, 1992a. Explanatory notes. In Behrmann, J.H., Lewis, S.D., Musgrave, R.J., et al., Proc. ODP, Init. Repts., 141: College Station, TX (Ocean Drilling Program), 37-71. 1992b. Site 859. In Behrmann, J.H., Lewis, S.D., Musgrave, R.J., et al., Proc. ODP, Init. Repts., 141: College Station, TX (Ocean Drilling Program), 75-157.

1992c. Site 862. In Behrmann, J.H., Lewis, S.D., Musgrave, R.J., et al., Proc. ODP, Init. Repts., 141: College Station, TX (Ocean Drilling Program), 301-341.

, 1992d. Site 863. In Behrmann, J.H., Lewis, S.D., Musgrave, R.J., et al., Proc. ODP, Init. Repts., 141: College Station, TX (Ocean Drilling Program), 343-446.

Skinner, B.J., Erd, R.C., and Grimaldi, F.S., 1964. Greigite, the thio-spinel of iron; a new mineral. Am. Mineral., 49:543-555.

Snowball, I., and Thompson, R., 1988. The occurrence of greigite in sediments from Loch Lomond. J. Quat. Sci., 4:121-125.

, 1990. A stable chemical remanence in Holocene sediments. $J$. Geophys. Res., 95:4471-4479.

Snowball, I.F., 1991. Magnetic hysteresis properties of greigite $\left(\mathrm{Fe}_{3} \mathrm{~S}_{4}\right)$ and a new occurrence in Holocene sediments from Swedish Lappland. Phys. Earth Planet. Inter., 68:32-40.

Spender, M.R., Coey, J.M.D., and Morrish, A.H., 1972. The magnetic properties and Mössbauer spectra of synthetic samples of $\mathrm{Fe}_{3} \mathrm{~S}_{4}$. Can. J. Phys., 50:2313-2326.

Tarduno, J.A., 1990. Absolute inclination values from deep sea sediments: a reexamination of the Cretaceous Pacific record. Geophys. Res. Lett., 17:101-104.

Tarling, D.H., 1983. Palaeomagnetism: Principles and Applications in Geology, Geophysics and Archaeology: London (Chapman and Hall).

Tauxe, L., Valet, J.-P., and Bloemendal, J., 1989. Magnetostratigraphy of Leg 108 advanced hydraulic piston cores. In Ruddiman, W., Sarnthein, M., et al., Proc. ODP, Sci. Results, 108: College Station, TX (Ocean Drilling Program), 429-439.

Wasilewski, P.J., 1973. Magnetic hysteresis in natural materials. Earth Planet. Sci. Lett., 20:67-72.

Westbrook, G.K., Carson, B., Musgrave, R.J., et al., 1994. Proc. ODP, Init. Repts., 146 (Pt. 1): College Station, TX (Ocean Drilling Program).

Zapletal, K., 1993. Effect of intergrowths of the ferrimagnetic and antiferromagnetic phases on the rock magnetic properties of natural pyrrhotites. Phys. Earth Planet. Inter., 76:151-162.

Date of initial receipt: 4 November 1993

Date of acceptance: 4 October 1994

Ms 141SR-015 